\title{
UNDERSTANDING SEXIST JOKE-TELLING IN THE INTERGROUP CONTEXT
}

\author{
A thesis submitted to the Faculty of Graduate Studies and Research \\ in Partial Fulfillment of the requirements for the degree \\ Masters of Arts
}

by

Emily Denis

Department of Psychology

Carleton University

September 2008

(C)2008 Emily Denis 


$\begin{array}{ll}\begin{array}{l}\text { Library and } \\ \text { Archives Canada }\end{array} & \begin{array}{l}\text { Bibliothèque et } \\ \text { Archives Canada }\end{array} \\ \begin{array}{l}\text { Published Heritage } \\ \text { Branch }\end{array} & \begin{array}{l}\text { Direction du } \\ \text { Patrimoine de l'édition }\end{array} \\ \begin{array}{l}\text { 395 Wellington Street } \\ \text { Ottawa ON K1A 0N4 } \\ \text { Canada }\end{array} & \begin{array}{l}\text { 395, rue Wellington } \\ \text { Ottawa ON K1A 0N4 } \\ \text { Canada }\end{array}\end{array}$

Your file Votre référence

ISBN: 978-0-494-43453-6

Our file Notre référence

ISBN: 978-0-494-43453-6

NOTICE:

The author has granted a nonexclusive license allowing Library and Archives Canada to reproduce, publish, archive, preserve, conserve, communicate to the public by telecommunication or on the Internet, loan, distribute and sell theses worldwide, for commercial or noncommercial purposes, in microform, paper, electronic and/or any other formats.

The author retains copyright ownership and moral rights in this thesis. Neither the thesis nor substantial extracts from it may be printed or otherwise reproduced without the author's permission.
AVIS:

L'auteur a accordé une licence non exclusive permettant à la Bibliothèque et Archives Canada de reproduire, publier, archiver, sauvegarder, conserver, transmettre au public par télécommunication ou par l'Internet, prêter, distribuer et vendre des thèses partout dans le monde, à des fins commerciales ou autres, sur support microforme, papier, électronique et/ou autres formats.

L'auteur conserve la propriété du droit d'auteur et des droits moraux qui protège cette thèse. $\mathrm{Ni}$ la thèse ni des extraits substantiels de celle-ci ne doivent être imprimés ou autrement reproduits sans son autorisation.
In compliance with the Canadian Privacy Act some supporting forms may have been removed from this thesis.

While these forms may be included in the document page count, their removal does not represent any loss of content from the thesis.
Conformément à la loi canadienne sur la protection de la vie privée, quelques formulaires secondaires ont été enlevés de cette thèse.

Bien que ces formulaires aient inclus dans la pagination, il n'y aura aucun contenu manquant.

\section{Canada}




\begin{abstract}
The present study explored the oft-overlooked negative effects of humor, especially if that humor is directed at the ingroup. Female participants $(\mathrm{N}=143)$ were exposed to disparaging or non-disparaging jokes about women. Importantly, the joketeller gender was also varied and identification with the ingroup (women) was assessed as a potential moderator. Results showed that only joke-type (and not joke-teller gender or ingroup identification) influenced females' appraisals and emotional and behavioural reactions. Hierarchical regressions showed that females perceived disparaging jokes as less funny, more sexist, as well, they elicited more anger, shame, anxiety, and endorsed more collective, individual, and avoidant behaviour relative to non-disparaging jokes. Further, anger mediated the relation between females' appraisals and collective action endorsements; anxiety mediated the link between females' appraisals and individual action endorsements; and shame and anxiety each mediated the relation between females' perceived joke sexism and avoidant endorsements toward the joke-teller. These findings highlight the importance of examining negative consequences of ingroup-directed humor on ingroup members, particularly to understand the relation between appraisals and reactions to such humor. Findings are discussed in terms of manipulation strength, study methodology, and future directions for research.
\end{abstract}




\section{Acknowledgements}

I would like to extend my thanks and gratitude to my supervisor, Dr. Kimberly Matheson. I am thankful for her continued guidance and support, her constructive comments and her remarkable knowledge of social psychology and statistical research.

I would also like to extend my thanks and gratitude to Dr. Michael Wohl for his valuable comments, enthusiasm, and his creative input and support throughout this study.

I would also like to acknowledge my fellow lab members. Their love of research and ongoing support made it easy to feel part of a research family.

Finally, I would like to thank my family and friends, and especially my fiancé and best friend, Guillaume Labelle, for their ongoing encouragement and positive outlook. All of your patience, love, and support kept me motivated during the last two years and throughout my life. 


\section{Table of Contents}

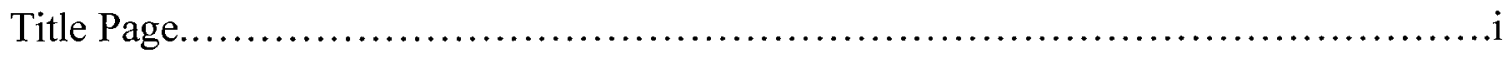

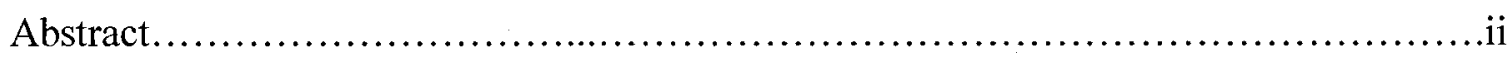

Acknowledgements...........................................................

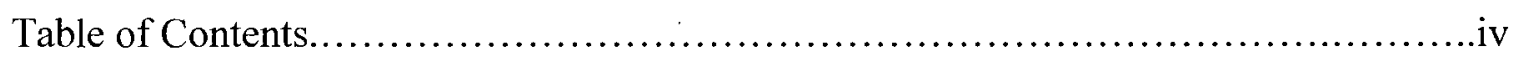

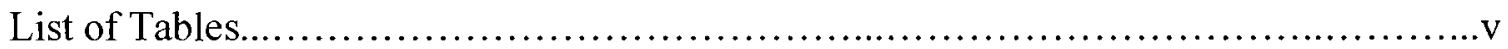

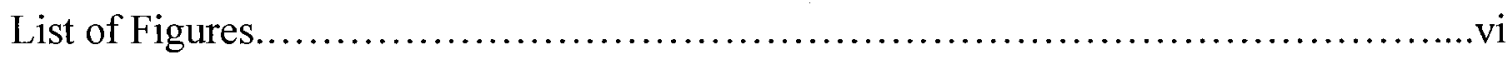

List of Appendices........................................................... vii

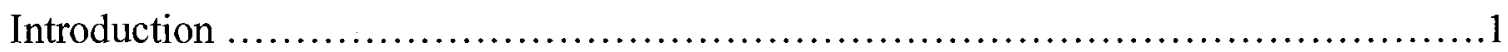

Method................................................................. 16

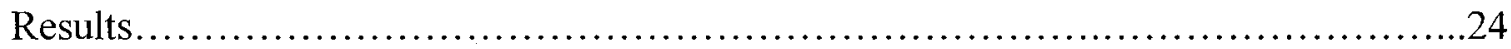

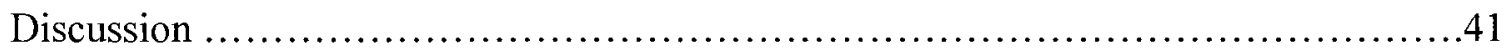

References...............................................................60

Appendices.............................................................. 75

Footnotes.............................................................. 94 


\section{List of Tables}

Table 1. Pearson Zero-Order Correlations between Appraisals, Negative Emotions and Action Endorsements.

Table 2. Summary of Descriptive Statistics.

Table 3. Summary of Hierarchical Regression Analyses for Variables Predicting Joke Funniness.

Table 4. Summary of Hierarchical Regression Analyses for Variables Predicting Joke Sexism

Table 5. Summary of Hierarchical Regression Analyses for Variables Predicting Anger.

Table 6. Summary of Hierarchical Regression Analyses for Variables Predicting Shame.

Table 7. Summary of Hierarchical Regression Analyses for Variables Predicting Anxiety.

Table 8. Summary of Hierarchical Regression Analyses for Variables Predicting Collective Action.

Table 9. Summary of Hierarchical Regression Analyses for Variables Predicting Individual Action.

Table 10. Summary of Hierarchical Regression Analyses for Variables Predicting Avoidant Endorsements.

Table 11. Summary of Multiple Mediation Analyses involving Appraisals and Collective Endorsements.

Table 12. Summary of Multiple Mediation Analyses involving Appraisals and Individual Endorsements.

Table 13. Summary of Multiple Mediation Analyses involving Appraisals and Avoidant Endorsements. 


\section{List of Illustrations}

Figure 1. Mediation of joke appraisals and collective endorsements by anger.

Figure 2. Mediation of joke appraisals and individual or avoidant action endorsements by shame and anxiety. 


\section{List of Appendices}

Appendix A. Pre-Joke Measures

Appendix B. Disparaging and Non-disparaging Joke Conditions

Appendix C. Post-Joke Measures 
Introduction

Humor can be regarded, by and large, as an enjoyable, amusing, and socially reinforcing form of communication. The beneficial aspects of humor have recently been a focus of research attention, particularly given the recent flourishing of positive psychology (Seligman, 2002; Seligman, Steen, Park \& Peterson, 2005; Vaillant, 2000). The benefits of humor include bringing people together by relieving tension and identifying common interests, feelings and attitudes (Lynch, 2002; Meyer, 2000); individuals who laugh more and use humor to cope tend to experience less negative affect when encountering stress (Kuiper, Martin, \& Olinger, 1993; Lefcourt \& Martin, 1986; Martin \& Lefcourt, 1983); and, a good sense of humor is associated with higher selfesteem, increased sociability, and reduced feelings of hopelessness, depression and other forms of poor psychological and physical well-being (Cogan, Cogan, Waltz, \& McCue, 1987; Kazarian \& Martin, 2004; Martin, Kuiper, Olinger, \& Dance, 1993; McGhee, 1999; Overholser, 1992).

Despite the beneficial aspects of humor, negative effects of humor are also apparent. Specifically, who the joke-teller is relative to the audience in terms of social group membership may be important (Ford \& Ferguson, 2004; Tropp \& Bianchi, 2007). For instance, jokes or comments that disparage the ingroup's identity are perceived to be less funny and more offensive when told by an outgroup joke-teller. Jokes targeted to one's own group by an outgroup member may be interpreted as a form of group-based criticism, and hence elicit intergroup tension and hostility toward the joke-teller on behalf of the ingroup (Hornsey, De Bruijn, Creed, Allen, Ariyanto, \& Svensson, 2005; Hornsey, Oppes, \& Svensson, 2002). In effect, group members may interpret disparaging jokes told 
by someone from the outgroup as threats to their social identity (Brown \& Pinel, 2003; Maass, Cadinu, Guarnieri, \& Grasselli, 2003). In contrast, the negative interpretation of disparaging jokes that originate from the ingroup, may not be evident. In effect, the humorous disparagement of a group may be experienced differently depending on the source of the joke, even when the same message is told. Such differences in the reactions toward disparagement of a group, and in particular women, in the context of humor were the focus of the present study.

Reactions to ingroup-disparaging jokes might further vary as a function of several social variables. In particular, the extent to which individuals identify with their group may influence how they respond to identity threats (Jetten, Postmes, \& McAuliffe, 2002; Jetten, Spears, \& Manstead, 1997). For instance, in the face of a threat to their group, low identifiers are more likely to distance themselves from their group, whereas high identifiers are more likely to demonstrate a favourable ingroup bias and defend their group's positive status (Hornsey et al., 2002; Jetten \& Spears, 2003; Jetten et al., 2002; Tajfel \& Turner, 1979). Thus, the level of women's gender identification may be pertinent to their reactions to humor that is disparaging to their group, particularly when it is expressed by a male outgroup member.

\section{Social Identity Theory}

The groups that individuals belong to can be a powerful determinant of their social behaviour. Social identity theory (Tajfel, 1978; Tajfel \& Turner, 1979) argues that individuals recognize their membership in various social groups, and that they are motivated to compare positively relative to other groups. As a result, individuals are likely to act more favorably toward ingroup as opposed to outgroup members, and to 
endorse positive ingroup stereotypes that differentiate the ingroup from the outgroup (Abrams \& Hogg, 1990; Tajfel, 1978).

When a social identity is threatened (e.g. when the ingroup is stigmatized, devalued or criticized), group members may respond with a range of emotions including anger (Mackie, Devos, \& Smith, 2000; van Zomeren, Spears, Fischer, \& Leach, 2004), contempt (Yzerbyt, Dumont, Wigboldus, \& Gordijn, 2003), shame (Matheson \& Anisman, 2008), and anxiety (Stangor \& Crandall, 2003). The particular emotion expressed depends on group members' appraisals of the event as harmful or threatening to the self (Frijda, 1986; Smith \& Ellsworth, 1985), and attributions for the cause of the event (Pennekamp, Doosje, Zebel, \& Fischer, 2007). When ingroup members' identities are threatened and the outgroup is viewed as responsible for the negative treatment, anger is likely to result (Pennekamp et al., 2007). Shame may also be felt in response to injustices directed towards one's group. When a discriminatory comment is directed toward an individual's group and perceived to reflect a personal weakness stemming from group membership that is beyond his or her control, he or she may feel ashamed or humiliated (Branscombe, Slugoski, \& Kappen, 2004; Lickel, Schmader, \& Barquissau, 2004). Finally, anxiety may be experienced when a threatening event is perceived to reflect uncertainty and a lack of personal control on behalf of the individual (Frijda, 1986; Roseman, 1984).

The emotions experienced in response to an identity threat have implications for the actions taken to contend with the situation (Hercus, 1999; Mackie \& Smith, 2004; Wright, Taylor \& Moghaddam, 1990). Specifically, anger in response to an identity threat has been associated with more action-oriented endorsements, such as the urge to attack or 
confront the source of disparagement (Mackie et al. 2000; Matheson \& Anisman, 2008; van Zomermen et al., 2004). Shame has been associated with the urge to escape or withdraw the source of the disparagement (Lickel et al., 2004; Tangney, 1995; Wicker, Payne, \& Morgan, 1983) and lower acceptance of one's inferior status, despite the lack of a confrontational response (Matheson \& Anisman, 2008). Anxiety has also been associated with more avoidant behaviour (Gordijn, Wigboldus, \& Yzerbyt, 2001; Frijda, 1986; Lewis \& Douglas).

To the extent that disparaging humor is perceived as a threat to the ingroup, and that these appraisals may in turn evoke emotional and behavioural reactions to threat, the intergroup effects and negative impact of such humor on females are important to investigate.

Individual differences in strength of identification. Individuals' social identities can be affected by situational cues that make one identity more salient than another, but there also exist individual differences in the extent to which group members align themselves with the groups they belong to (Brown, 2000; Tajfel, 1979). Not surprisingly, group members' reactions to an identity threat vary as a function of the strength of their identification with the group. For example, women who identified highly with their gender were more likely to perceive personal threat in response to sexism and were more likely to experience depression and reduced self-esteem than did women who were considered low identifiers (McCoy \& Major, 2003). In other situations, when the group was faced with a potential threat, high identifiers were more likely to exhibit anger and contempt toward the outgroup (Ellemers, Spears, \& Doosje, 2002; Mackie et al., 2000). These variations in responses may reflect variations in the ingroup's status, in that, anger 
and contempt were more likely to be expressed by members of powerful groups relative to members in weak or submissive groups (Ellemers et al., 2002; Mackie et al., 2000).

Not surprisingly, levels of identification may also influence the actions group members endorse when their identity is threatened. Specifically, being more highly identified with one's group has been associated with greater confrontational collective responses to reduce threat and to defend group identity (Doosje, Ellemers, \& Spears, 1995; Jetten et al., 2002; Mackie et al., 2000). Low identifiers, on the other hand, tend to be selective in their commitment to the ingroup, and are more likely to align with the collective when they perceive that it is personally beneficial for them to do so, and to deny their status and distance themselves from their group when it is not. Indeed, numerous studies have established that low identifying group members are more likely to engage in more individualistic forms of self-protection following ingroup threat (Ellemers, Spears, \& Doosje, 1999; Hornsey et al., 2002, 2005; Jetten et al., 2002).

Group identification has also been conceptualized as a multidimensional construct representing an individual's positive emotional evaluations (termed 'ingroup affect'), similarity or connectedness to other ingroup members (termed 'ingroup ties') and cognitive awareness (termed 'centrality') toward his or her respective gender (Cameron, 2000). A multidimensional approach may be necessary to consider in that each dimension may play a different role in a different context (Cameron, 2001). For instance, centrality and ingroup ties may be important with regard to perceived discrimination in that the salience and commitment toward one's gender may be associated with appraisals and action-taking at the group level. Furthermore, ingroup affect may be associated with a reduced perception of discrimination (Cameron, 2001). 


\section{Humor in the Intergroup Context}

Humor may be viewed as a diverse and subjective communication medium through which people derive amusement, enjoyment, or laughter on a given theme or topic. As a form of communication, it entails both a speaker with intent and an audience who interprets what is said. The expression of one's interpretations, opinions, and beliefs about the self, the social or physical environments can be conveyed to an audience in a variety of ways for various reasons. The use of humor is thought to provide specific social functions that might have particular meaning in an intergroup context.

Specifically, humor in the group context may represent a form of social regulation by smoothing group interaction, sharing a collective identity, separating the group by creating social boundaries, or securing member compliance (Fine \& De Soucey, 2005). The specific function served may depend on characteristics of the speaker and audience, and in particular whether or not they are perceived as belonging to a common ingroup. In this regard, the joke-teller's group membership relative to the ingroup may be integral to how evaluations of the appropriateness, funniness, or offensiveness in jokes are made (Crandall, Eshleman, \& O'Brien, 2002; Ford \& Ferguson, 2004; Thomas \& Esses, 2004; Tropp \& Bianchi, 2007).

As noted, humor may be used in an intergroup context to smooth group interaction when disagreement or friction exists between groups. Making light of a situation instills the idea that quarrelling members should reconcile, put their differences aside, and laugh together because they have done so in the past (Fox, 1990). In this sense, joking should downplay the seriousness or threat emanating from some event, or provide a platform to resolve an upsetting event (Yedes, 1996). Furthermore, the 
separation of groups through the creation of social boundaries ensures that humor reinforces intergroup conduct and goals without seeming oppressive. This form of social regulation underscores that humor is embedded in a particular group's social identity. In particular, many of the jokes may center on how one group is different (or better, for example) than another.

Humor may also have a function in the intragroup context, particularly in relation to issues on which group members disagree with one another. Humor may achieve social regulation by sharing a collective identity among group members. In this regard, group traditions and goals may be re-examined to promote group involvement and solidarity, and reduce tensions for new members entering the group. To the extent that group members can joke, understand, and get along with one another, they establish their group as welcoming and potentially vital to the new members' social identities. Finally, humor is powerful in the intragroup context because it secures the compliance of members. As such, group members may be tested with jokes as a way of ensuring their commitment to group norms (Fine \& De Soucey, 2005). By pointing out deviant behaviour in a humorous manner, a joke-teller might expect group members to pledge their agreement by laughing or smiling; those who do not follow suit may be suspected of straying from the group.

Certainly, using humor to achieve these social functions means that joking can serve as a powerful communication tool - one that can accomplish social regulation by downplaying the seriousness of certain topics or by threatening the integrity or social identities of those who are targeted in jokes or humorous comments. As a result, the same jokes might be interpreted differently depending on the speaker's group status vis a vis 
the audience. Moreover, the degree to which these jokes are interpreted as threats and how the targeted group members respond to these threats are of particular interest.

Repressive humor: Disparagement from the outgroup. Repressive humor targets individuals or groups that are considered strange, deviant, and presumably unlike the joke-teller, including outgroups. It may include poking fun at the weaknesses or misfortunes of others (Lynch, 2002; Meyer, 2000), or more commonly, joking about individuals who are viewed to be inferior to the joke-teller (Wills, 1981). Research on repressive humor has demonstrated that downward comparisons of groups or individuals are usually directed at "safe", or lower status targets (Wills, 1981). Indeed, when people are able to choose their target for a joke, those with lower status (e.g. minority groups, women) are often preferred and found to be funnier (Terrion \& Ashforth, 2002) over those with a neutral or equal group status (Thomas \& Esses, 2004; Wicker, Barron, \& Willis, 1980; Wills, 1981).

One could argue that humor is intended to alleviate distress and tension with an audience (Barnes, Palmary, \& Durrheim, 2001; Fine \& De Soucey, 2005; Neitz, 1980), and so should not be perceived as an identity threat. In this sense, such humor has been regarded as a means to extend "positive politeness". However, others suggest that this is a socially appropriate euphemism for criticizing another individual or group (Brown \& Levinson, 1987), and that in reality, this genre of humor is an effective way to improve persuasion or gain power (Ford \& Ferguson, 2004; Hiller, 1983; Hornsey, Spears, Cremers, \& Hogg, 2003; Lynch, 2002; Meyer, 2000; Thomas \& Esses, 2004; Wills, 1981; Zajdman, 1995). Repressive jokes may also be told by a joke-teller who seeks to attain personal goals of self-enhancement through the ridicule of others (La Fave, 
Haddad, \& Maesen, 1996; Wills, 1981). Taking these objectives together, repressive humor may serve to emphasize group boundaries and disempower the targeted group. In actuality, the interpretation of disparaging humor may be fairly ambiguous when it emanates from an outgroup member. To the extent that ingroup members are more likely to expect the outgroup to be untruthful (Insko \&Schopler, 1998), to have illintent toward them (Hornsey, Trembath, \& Gunthorpe, 2004), and to discriminate against them (Vivian \& Berkowitz, 1992), such humor may, indeed, be regarded as a threat. In this regard, LaFrance and Woodzicka (1998) examined the impact of sexist jokes on women by assessing their verbal and non-verbal responses and ambivalent attitudes toward their gender. They found that women rated pre-recorded sexist jokes told by a male to be significantly less funny and less amusing than nonsexist jokes. Women were also more hostile, disgusted, angry, determined, and surprised after hearing sexist jokes than nonsexist jokes. Some women also expressed non-verbal responses such as covering their faces, a response associated with embarrassment. It should also be noted that although earlier research suggested that women were more likely to approve of and enjoy repressive humor more than their male counterparts (Cantor, 1976; Losco \& Epstein, 1975; Zillmann \& Cantor, 1976) ${ }^{1}$, it is very possible that the gender identification of women in these earlier studies differed markedly from that of women 20 years later. If so, it could be expected that highly identified women would find such repressive humor less amusing and more infuriating than women whose gender identification is weak.

As noted earlier, repressive humor may elicit a particular set of negative emotions from targeted group members. For instance, survey research on sexual harassment in the nursing industry found that female nurses experienced high levels of anger and 
embarrassment, as well as anxiety, humiliation and irritability when sexist jokes were made by either a male co-worker, physician, or patient (Dan, Pinsof \& Riggs, 1995; Paludi \& Barickman, 1991). Furthermore, when asked how nurses behaved in response to sexist comments, the most commonly reported behaviour included ignoring and avoiding the harasser. Similarly, LaFrance and Woodzicka (1998) found that when a male told sexist jokes, females responded with emotions such as anger and embarrassment. However, they further noted that when these events were hypothetical, females expressed anger and that they would act by leaving a discriminating event or challenging a male harasser. Yet, when they were actually confronted with a sexually harassing situation in a simulation experiment, they responded instead with fear and took no action (LaFrance \& Woodzicka, 2001). Related to this, Swim and Hyers (1999) also found that although women were more likely to privately endorse confrontational action toward a man who made sexist comments towards them, only $16 \%$ of the women actually carried through with their intent to confront the man's sexist remarks. An activist orientation, or a strong commitment to fighting sexism, was more associated with females' likelihood of publicly confronting sexist remarks made by a man. This type of activism is typically linked to higher ingroup identification. Thus, it may be that exposure to sexist humor might elicit an array of negative emotions, including anger, shame and anxiety. However, group identification may be critical in moderating which emotion predominates and the resulting actions that are taken.

Self-deprecating humor. In self-deprecating humor, the joke-tellers are themselves the target of jokes. Such self-effacement can range from merely poking fun to harshly criticizing oneself, and may cover topics such as one's own abilities, 
experiences, or social groups (including gender or ethnicity). Thus, self-deprecating and repressive humor might be identical without reference to the group memberships of the speaker and audience, differing only in reference to them versus us. Because selfdeprecating humor focuses on joking about oneself or one's own group, it is perhaps most likely to be employed to smooth interpersonal interactions, and to enhance recognition of the experiences associated with a common collective identity. In fact, findings of previous research supports these social functions of humor in that, selfdeprecating humor may be used to preempt negative comments or criticism from the outgroup (Cutler, 2006), to gain the sympathy and approval of others (Kirsh \& Kuiper, 2003; Meyer, 2000), and to promote camaraderie between groups (Lynch, 2002; Meyer, 2000). Thus, unlike the humorous deprecation emanating from an outgroup member, it appears that intragroup deprecation may not be experienced as a threat to the group. Instead, when a member challenges the group's identity, it may be viewed as a way of extending openness to ingroup differences (Matheson, Cole, \& Majka, 2003), and as a mechanism for group reform and growth (Hornsey et al., 2002, 2005).

Another use of this genre may be to confront stereotypes or the perceived status of one's own group (Hiller, 1983). More specifically, while putting one's own group (or oneself) down for humor's sake may seem like a confession or plea for acceptance, this genre may serve hidden intents, namely to expose the guise of overt conflict and to rise against the beliefs of dominant social groups (Hiller, 1983). This latter use of selfdeprecating humor is thought to be characteristic of the feminist movement, where the self-confident woman indulges in self-criticism by laughing at traditional gender roles (Walker, 1981). To the extent that this is the case, one might expect that group members 
who most strongly identify with their group will be most appreciative of this form of humor when it is expressed by another member of the ingroup.

Perhaps because self-disparagement serves several positive intragroup functions, female comediennes are more likely to use this type of humor than men (Levine, 1976), and women rated female self-disparagers as wittier and more appealing than did men. This preference might be related to viewing self-disparagement as a form of sharing a narrative (Lampert \& Ervin-Tripp, 1998). This positive reaction of self-disparagement has also been reported among members belonging to minority groups (Hornsey et al., 2002; Nemeth \& Owens, 1996; Tropp \& Bianchi, 2007), and the propensity to express self-deprecating jokes that address minority-majority distinctions are also prevalent among other minority groups, namely people of Black, Hispanic, and Jewish origin (La Fave \& Mannell, 1976; Rappoport, 2005). In effect, when an ingroup member puts down their own group, members might actually interpret the disparager's criticisms as constructive and deliberately made on behalf of the group's best interests. This said, others have suggested that the enjoyment of self-deprecating humor might be a means to cope with anxiety, particularly within groups that experience higher levels of oppression than others (Ziv, 1984, 1998).

In contrast to repressive humor, disparaging humor that originates from the ingroup may be interpreted quite differently. For example, a study by Mitchell (1977) found that women perceived jokes about rape as funny when a female was the joke-teller, but not when the joke-teller was male. This response is likely related to the fact that females are usually the victims of rape (and men the aggressors), and that when a female tells such jokes, they are interpreted more positively because they share a similar reality 
as women. While the emotional and behavioural responses to self-disparaging female humor have not been empirically documented, social identity literature suggests that a considerable ingroup bias toward a female joke-teller would lead to positive affect and bonding behaviour on behalf of the ingroup audience (Hornsey, Oppes, \& Svennson, 2002), rather than eliciting the negative emotions evident when the humor is expressed by a male.

\section{The Present Study}

Extensive research has focused on the beneficial aspects and appreciation of humor. However, studies on the potential negative effects of group-based humour in an intergroup context have been seldom explored. In the present investigation, women's cognitive, emotional, and behavioural reactions to humor that involved ridiculing their own group were assessed as a function of the group membership of the joke teller. Specifically, disparaging humor was expressed by a member of the outgroup (repressive humor) or by a member of the ingroup, another woman (self-disparaging). Women's reactions to these forms of humor were compared to their reactions to group-neutral jokes expressed by a male or a female (i.e., expressing 'observational' humor, which entails target-neutral jokes about odd, unexpected, or absurd situations). As either repressive or self-disparaging humor could be regarded as a form of identity threat, it was anticipated that individual differences among women in the strength of their gender identification would play a key moderating role in how they responded to these forms of humor. Thus, in the present study, it was hypothesized that:

1) women's interpretation of female-disparaging versus non-disparaging (observational) jokes would be moderated by joke-teller gender and gender 
identification. Specifically, among highly identified women, disparaging jokes told by a male would be appraised as less funny, more offensive, aggressive, and sexist compared to when told by a female; this difference of interpretation as a function of joke-teller gender was not expected among women with low gender identification. No differences were expected in appraisals of the nondisparaging jokes as a function of the gender of the joke-teller or gender identification.

2) women's emotional reactions to female-disparaging versus non-disparaging jokes would be moderated by joke-teller gender and gender identification. Specifically, among highly identified women, disparaging jokes told by a male elicit more anger relative to disparaging jokes told by a female; among women with a low gender identification, disparaging jokes told by a male were expected to elicit greater shame and anxiety relative to disparaging jokes told by a female. No differences in emotional reactions to the non-disparaging jokes were expected as a function of the gender of the joke-teller.

3) women's action endorsements to female-disparaging versus non-disparaging jokes will be moderated by joke-teller gender and gender identification. In particular, among highly identified women, disparaging jokes told by a male would elicit higher collective and confrontational action endorsements; among women with a low gender identification, disparaging jokes told by a male elicit were expected to elicit greater avoidance or individualistic actions relative to disparaging jokes told by a female. No differences as a function of 
joke-teller or gender identity were expected in the non-disparaging joke condition.

4) appraisals, emotions, and actions endorsements would be correlated, in that appraisal of disparaging jokes as less funny, more offensive, more aggressive, and sexist would be positively related to negative emotions (i.e. anger, shame, anxiety) and to action endorsements compared to non-disparaging jokes.

5) negative emotional reactions were expected to mediate the effects of the joke appraisals on women's action endorsements. In particular, anger was hypothesized to mediate the relation between appraisals and collective action endorsements (Figure 1); and shame and anxiety were expected to mediate the relation between appraisals and individualistic or avoidant action endorsements (Figure 2).

Figure 1. Mediation of joke appraisals and collective endorsements by anger.

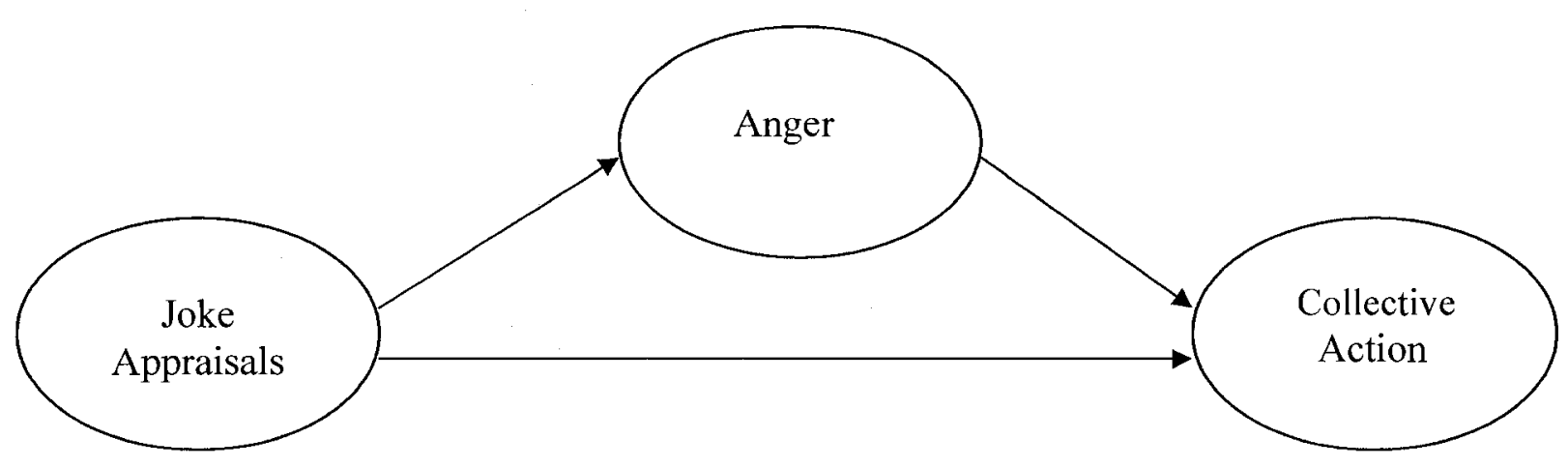


Figure 2. Mediation of joke appraisals and individual or avoidant action endorsements by shame and anxiety.

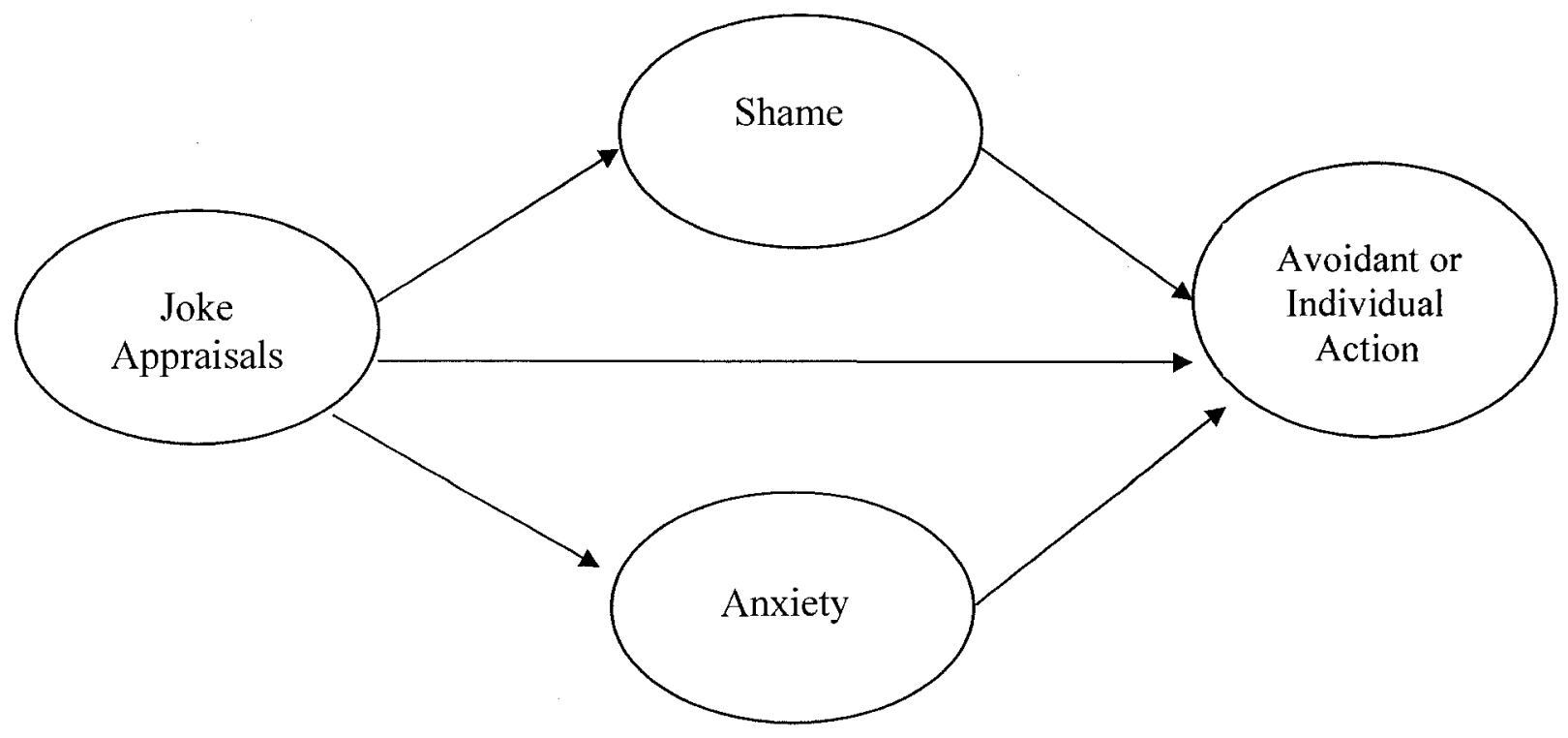

Method

\section{Participants}

Introductory psychology students from Carleton University were invited to participate in a study on the perception of humor. The final sample consisted of 143 females aged between 16 and 31 years of age $(M=19.25, S D=2.20) .{ }^{2}$ Of those participants who reported ethnic background, the majority were Euro-Caucasian $(n=95$; $66.4 \%)$, Black $(n=13 ; 9.1 \%)$, South Asian $(n=9 ; 6.3 \%)$, Arab/West Asian $(n=7$; $4.9 \%)$, Chinese $(n=7 ; 4.9 \%)$, Latin American $(n=4 ; 2.8 \%)$, or Aboriginal Canadian $(n=$ $1 ; 0.7 \%$ ), and 7 participants identified their ethnic background as Other (4.9\%). All participants received an experimental credit or monetary compensation for taking part in the study 


\section{Procedure}

Participants were run in same-sex group sessions. To ensure confidentiality and privacy, participants were seated at individual desks separated by cardboard dividers. Participants read and signed an informed consent form at the outset of the study. They then filled out an initial questionnaire booklet assessing background demographic information and current mood (see Appendix A). After completing the premeasures, each session of participants was randomly assigned to read one of four versions of a newspaper article describing a comic who might be coming to perform on campus and to complete the corresponding survey. The articles followed a similar format to the online version of the Charlatan, a student-operated campus newspaper and invited students to rate jokes by a comedian who might perform on campus for a monthly event that would be sponsored by the University's student association. Participants were invited to provide their feedback on the prospective comic by rating the funniness of each of six joke excerpts from a previous comedy routine (see article and versions of corresponding survey in Appendix B). The jokes consisted of anonymous material gathered from the Internet and modified jokes from actual comedic routines. The jokes were piloted with 30 independent participants who rated the degree to which they found each joke to be funny, sexist, offensive, and previously known to them. Two sets of jokes ( 3 disparaging; 6 nondisparaging) were selected on the basis of being viewed as moderately funny, as either low (observational) or high in terms of perceived sexism and offensiveness, and as being generally unfamiliar to the joke evaluators.

The female-disparaging joke condition consisted of six jokes: three sexist jokes, and three non-sexist jokes (i.e. observational jokes) of similar length that were included 
as 'fillers' to diminish demand characteristics. The presentation of the jokes varied in an asymmetrical order, with sexist jokes placed in the second, fifth, and sixth positions relative to the non-disparaging jokes. The non-disparaging condition consisted of six jokes - the same three observational jokes from the disparaging condition, plus three other non-disparaging jokes chosen from the pilot session. Joke-teller gender was manipulated by having a picture and name of either a male or female on each page of the survey. Each joke was rated by participants in order to maintain the cover story's believability as an actual online survey, and to enhance engagement with the materials.

Following this task, participants completed a questionnaire booklet that assessed their mood reactions and overall appraisals of the jokes, action endorsements regarding the comic's pending visit to campus and a gender identification scale (see Appendix C). Gender identification was also measured in a prior mass testing of Introductory Psychology students; however, due to difficulty recruiting participants who initially completed this measure, the scale was included at the end of the questionnaire booklet as well.

Finally, participants were verbally debriefed regarding the true nature of the study. A second informed consent for the use of the data was obtained after explaining that deception was involved. Participants were provided with contact information in the event that they wished for additional information about the study, to report any ethical concerns, or to contact health or equity services available on campus.

Measures

Manipulation checks. To ensure that participants properly evaluated the jokes and provided feedback for the appropriate conditions, immersed among the appraisal items 
were 4 manipulation check items. Specifically, participants reported the gender of the joke-teller, and rated the degree to which the comic was exploitive of certain groups (e.g. women), 'hypocritical or two-faced' (especially pertinent for the perception of selfdeprecating joke type), or 'gives the impression that he or she does not like women'. These latter three items were rated on a 7-point Likert scale of 0 (Not At All) to 6 (Extremely). The degree to which the comic was 'hypocritical or two-faced' was moderately positively associated with the degree to which the comic was "exploitive of certain groups (e.g. women)' $(r=.57, p<.001)$, and 'gives the impression that he or she does not like women' $(r=.60, p<.001)$. However, the appraisals that the comic was exploitive and gave the impression that he or she does not like women were highly correlated $(r=.83, p<.001)$. Since these latter two items were highly correlated, they were combined into one mean score. Given that repressive humor should not be described by a hypocritical or two-faced comedian, it was analysed separately despite the moderately high correlations with the other items.

Joke appraisals. After reading all of the jokes, participants provided ratings of their overall impressions of the comic and his or her jokes on 18 items, including four of interest, namely funniness, offensiveness, aggressiveness, degree of sexism, as well as 14 filler items such as creativity, evaluator's likelihood to repeat, and written quality of the jokes. Appraisals were measured on a 7-point Likert scale ranging from 0 (Not At All) to 6 (Extremely). Joke funniness was negatively correlated with ratings of joke offensiveness $(r=-.36, p<.001)$, aggressiveness $(r=-.21, p<.05)$ and sexism appraisals $(r=-.28, p<.001)$, and these three appraisals were highly positively correlated with one another (correlations ranged from .65 to $.86, p \mathrm{~s}<.001$ ). Since these latter three joke 
appraisals were all highly correlated with one another, they were combined into one appraisal scale, and named the 'sexist' appraisal scale (Cronbach's $\alpha=.88$ ). Thus, subsequent analysis included only two indexes of joke appraisal ('funny' and 'sexist').

Emotions. Using a 7-point Likert scale of 0 (Not At All) to 6 (Extremely), a set of 14 mood items was assessed after reading and rating all of the jokes. These included several humor-related positive mood adjectives to reduce demand characteristics, including laughing, happy, pleased, and cheerful, along adjectives tapping into the mood dimensions of interest, namely anger, shame, and anxiety. The anger scale comprised the mean ratings of "annoyed" and "angry" $(r=.78, p<.001)$, the shame scale comprised the mean ratings of "personally embarrassed" and "ashamed" $(r=.46, p<.001)$, and the anxiety scale consisted of the mean ratings of "distressed", "out of place", and "uncomfortable" (Cronbach's $\alpha=.81$ ). The three negative emotions of interest were positively correlated with one another (Table 1).

Action endorsements. Participants rated their endorsements of 15 actions to determine their behavioural intentions in the event that the comedian came to perform on campus. Using a Likert scale ranging from 0 (Not At All) to 6 (Extremely), these actions reflected varying degrees of acceptance of one's inferior status (e.g. "The comic can come to campus, but I have no interest in going to hear him or her"), whether the actions were acceptable within societal norms (normative actions, e.g. "I would make a point of telling my friends not to go see this comic if she or he came to campus") versus outside of societal norms (confrontational actions, e.g. "If CUSA still allowed the comic to perform, I would try to be one of the first people at the event and heckle or boo the comic"), or that involved doing things on one's own ("Go to the media to express how 
inappropriate I think this comic is and that they should not come to campus") versus joining a collective ( "I would be willing to join others in a protest against this comic's performance at the University").

Although the development of these items was initially based upon a model of collective action described by Wright, Taylor and Moghaddam (1990), because several items appropriate to the experimental context were included in the present study, a principal components analysis was conducted to reduce the items into relevant action endorsement dimensions. However, the principal components analysis did not yield the expected interpretable dimensions for endorsements scales, as items presumed to reflect theoretically distinct dimensions loaded onto common factors in a manner that did not make intuitive sense (i.e. individual actions with acceptance statements, collective actions with individual actions, etc.). Thus, the investigator selected items to represent broader action dimensions based on theoretical considerations and acceptable inter-item reliabilities (collective action, individual action, and avoidant/withdrawal tendencies).

First, the collective action endorsements scale comprised two statements that supported the extent to which one would advise or join others in group-based activities to contest the comedian's pending visit to campus ('I would make a point of telling my friends not to go see this comic if he or she came to campus' and 'I would be willing to join other in a protest against the comic's performance at the University, $r=.55, p<$ .001). The individual action endorsements scale comprised five statements that reflected the extent to which one would endorse personal or individual action to contest the comedian's pending visit to campus (Cronbach's $\alpha=.80$ ). These items included writing and personally complaining to the sponsoring association, signing a petition disputing the 
comic's attendance, being personally disruptive at the event, and going to a local media source to argue against the comic's attendance. Lastly, the avoidant endorsements scale involved two statements that reflected a general intent to exclude oneself or refrain from seeing the comedian's routine ('The comic can come to campus, but I have no interest in going to see him or her' and 'I hope this study shows CUSA that this comic should not be invited to come', $r=.42, p<.001)$. In general, the endorsements scales were positively correlated with one another (see Table 1).

Table 1

Pearson Zero-Order Correlations between Appraisals, Negative Emotions and Action Endorsements
1.
2.
3.
4.
5.
6.
8.

Appraisals

1. Funniness

2. Sexist $\quad-.32 * * * \quad--$

Emotions

3. Anger $\quad-.49 * * * \quad .80 * * * \quad--$

4. Shame $\quad-.13 \quad .59 * * * \quad .51 * * * \quad--$

5. Anxiety $\quad-.46^{* * *} \quad .69^{* * *} \quad .80^{* * *} \quad .56^{* * *} \quad--$

Endorsements

$\begin{array}{lllllll}\text { 6.Collective } & -.62 * * * & .52 * * * & .65^{* * *} & .29^{* * *} & .62 * * * & -\end{array}$

$\begin{array}{lllllll}\text { 7. Individual } & -.49 * * * & .59 * * * & .68 * * * & .38 * * * & .72 * * * & .79 * * *\end{array}$

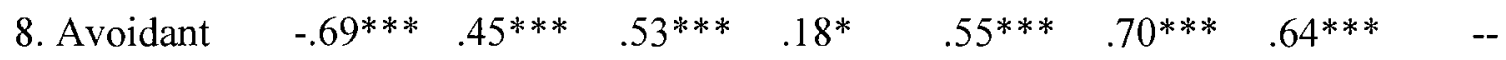

$* \mathrm{p}<.05, * * \mathrm{p}<.01, * * * \mathrm{p}<.001$ 
Gender identification. Gender identification was assessed using the Identification Scale (Cameron, 2004). This measure is comprised of 12 items rated on a 7-point Likert scale of 0 (Strongly Disagree) to 6 (Strongly Agree), tapping into three identity components, namely pride or ingroup affect (Cronbach's $\alpha=.84$ ), importance of the identity or centrality (Cronbach's $\alpha=.74$ ), and ties to other members of the group or ingroup ties (Cronbach's $\alpha=.87$ ). Negatively phrased items were recoded so that higher scores reflected higher identification on each of the three subscales. Although ingroup ties and centrality were mildly associated with one another $(r=.23, p<.01)$, neither of these subscales was related to ingroup affect $(r=.09, n s$, and $r=-.03, n s$, respectively).

Recall that for some participants identification was assessed prior to the study in mass testing $(n=44)$, whereas others completed it following the experimental session ( $n$ $=93$ ). An analysis of variance (ANOVA) indicated that post-joke ingroup affect was the only gender identification subscale that was not influenced by the two experimental variable manipulations, namely joke type, $F<1$, joke-teller gender, $F(1,89)=1.85$, $n s$, nor the interaction of these variables, $F<1$. Because ingroup affect was the only subscale that did not differ across the mass testing and post-experimental manipulation sessions, it was the only gender identification subscale used in further analyses. However, ingroup affect was lower when measured prior to the experimental session $(M=4.44, S D$ $=1.18)$ than following it $(M=5.28, S D=0.65), t=-4.47, p<.001$. Therefore, ingroup affect scores based on the mass testing session were adjusted by the mean difference $(0.85)$ in order to use the full sample of participants with bias. 


\section{Results}

Preliminary analyses were performed to provide descriptive statistics of the variables involved in the study, and to assess statistical assumptions in terms of outliers, skew and non-normality. Where necessary, outliers were brought to within 3 standard deviation units of the mean of the relevant variable when transformations of the data did not yield improved distributions. Main analyses entailed hierarchical regressions to examine the moderating effects of gender identification on the effects of two manipulated independent variables, namely joke type and joke-teller gender on joke appraisals, emotional reactions, and action endorsements. Finally, multiple mediation analyses were performed where significant associations between the predictor variables and appraisals, negative emotions, action endorsements were evident.

Descriptive Analyses

Joke appraisals. The mean appraisal scores pertaining to joke funniness and degree of joke sexism are shown in Table 2. Joke funniness was relatively normally distributed with minimal negative skew, while the degree of joke sexism was also relatively normally distributed but with mild positive skew. An examination of the $\mathrm{Z}$ scores revealed that all participant scores were within 3 standard deviations of the mean, establishing that these scores were within normal limits. In general, Table 2 shows that participants rated the jokes as moderately funny and mild-to-moderately sexist (albeit with wide variability).

Negative emotions. All negative emotion scales were positively skewed (see Table 2). An examination of the $Z$ scores revealed that 8 scores were beyond 3 standard deviation units. All outlying scores were brought within 3 standard deviations, which 
slightly improved the skew (final values presented in Table 2). Overall, anger had the highest mean and variability of all the emotions, followed by anxiety, then shame.

Action endorsements. As shown in Table 2, the collective and individual endorsements were non-normal and had high positive skew. The avoidant scale had moderate positive skew. Based on an assessment of $Z$ scores, 6 outlying scores in the individual endorsements scale were brought within acceptable limits. Among the action endorsements, avoidant endorsements had the highest mean and variability, followed by collective action and individual action.

Gender identification. As previously mentioned, only the ingroup affect dimension of gender identification was examined in further analyses. Ingroup affect was negatively skewed, however all standardized values were within 3 standard deviation units (Table 2).

Correlations between joke appraisals, negative emotions, action endorsements, and moderating variables. As shown in Table 1, joke funniness was negatively associated with anger and anxiety, but not shame, interpretation of the jokes as sexist was highly and positively correlated with all three of the negative emotions. Further, joke sexism was positively associated with all three forms of action, whereas funniness was associated with a lower likelihood of endorsing any of the actions. Similarly, the negative emotions were all positively correlated with action endorsements (Table 1). 
Table 2

Summary of Descriptive Statistics

\begin{tabular}{lcc}
\hline Measure & Mean $(S D)$ & Skewness \\
\hline Joke Appraisals & & \\
Funniness & $2.98(1.36)$ & -0.25 \\
Sexist & $2.12(2.29)$ & 0.42
\end{tabular}

Negative Emotions

$\begin{array}{lll}\text { Anger } & 1.29(1.50) & 1.07 \\ \text { Shame } & 0.40(0.69) & 1.47 \\ \text { Anxiety } & 0.82(1.14) & 1.37\end{array}$

Action Endorsements

$\begin{array}{lcc}\text { Collective } & 0.73(1.16) & 1.63 \\ \text { Individual } & 0.40(0.71) & 1.97 \\ \text { Avoidant } & 1.91(1.72) & 0.83\end{array}$

Gender Identification

Ingroup Affect $\quad 5.24(0.77) \quad-1.05$

Manipulation checks. As indicated earlier, participants were provided with a picture and name of the joke-teller and later asked to indicate if the joke teller was male or female. The manipulated joke-teller gender was compared to the reported joke-teller gender. Chi square analyses indicated that participants were, on the whole, accurate in identifying the gender of the joke-teller, with only 6 participants incorrectly identifying 
the joke-teller gender as female when it was male, $\chi^{2}(1, N=143)=120.89, p<.001$. These participants were excluded from all further analyses.

Perceptions of the jokes as derogatory of women were evaluated by examining two manipulation check items, namely the extent to which the comic had expressed an exploitive dislike of women, and that the comic was hypocritical or two-faced. A 2 (joke type: disparaging vs. non-disparaging) $\mathrm{x} 2$ (joke-teller gender) multivariate analysis of variance (MANOVA) revealed that there was a main effect of joke type, Pillai's trace = $0.74, F(2,132)=182.95, p<.001$ and joke-teller gender, Pillai's trace $=0.07, F(2,132)$ $=4.98, p<.001$. In particular, disparaging jokes were viewed as more exploitive $(M=$ 3.81, $S D=1.53)$ than the non-disparaging condition $(M=0.10, S D=0.32), F(1,133)=$ $368.66, p<.001, \eta^{2}=.391$, and the comic was viewed as more hypocritical or two-faced in the disparaging joke $(M=1.72, S D=1.71)$ versus non-disparaging joke condition $(M$ $=0.11, S D=0.47), F(1,133)=62.23, p<.001, \eta^{2}=.212$. As well, disparaging jokes were viewed as more hypocritical or two-faced when the joke-teller was female $(M=$ 2.33, $S D=1.77)$ than when the teller was male $(M=1.16, S D=1.46), F(1,133)=6.52$, $p<.05, \eta^{2}=.022$. Joke-teller gender effects were not found for the degree of exploitive dislike of women, $F<1$, ns. Thus, on the whole, the manipulations appeared to have been successful, in that disparaging jokes were indeed found to be more exploitive and related to the dislike of women than the non-disparaging jokes.

\section{Main Analyses}

To investigate the impact of ingroup affect (i.e., gender identification), joke type (gender disparaging coded 0 vs. non-disparaging coded 1), and joke-teller gender (male coded 0 vs. female coded 1) on joke appraisals, emotions, and action endorsements, a series 
of hierarchical regression analyses (one for each of the outcome variables) was performed. As a pre-existing individual difference variable, ingroup affect was entered at the first step, followed by the main effects of the manipulated variables, joke type and joke-teller gender on the second step. The two-way interactions (cross-products) among the three predictor variables were entered on the third step, and finally, their 3-way interaction on the final step. Joke appraisals. Two hierarchical regressions were conducted to assess the effects of ingroup affect, joke type and joke-teller gender on joke appraisals, namely perceived funniness and sexism. As shown in Table 3, only joke type predicted joke funniness, in that the non-disparaging jokes were seen as funnier $(M=3.27, S D=1.32)$ than the groupdisparaging jokes $(M=2.70, S D=1.35)$.

Table 3

Summary of Hierarchical Regression Analyses for Variables Predicting Joke Funniness $(N=137)$

\begin{tabular}{ccccc} 
Predictor & $\Delta \mathrm{R}^{2}$ & $r$ & $\beta$ & $\begin{array}{r}\text { semi- } \\
\text { part } r^{2}\end{array}$ \\
\hline
\end{tabular}

Step 1 .002

ID .05 .05 .002

Step 2 $.044^{*}$

Joke Type

$$
.21 * *
$$

$.21^{*}$

$.040^{*}$

Teller Gender

$-.03$

$-.04$

.001

Step 3

.028

ID X Joke Type

$\begin{array}{rr}.19^{*} & -.93 \\ -.03 & -.46\end{array}$

.020

ID X Teller Gender

$-.03-.46$

.004 
Joke Type X Teller Gender

.06

$-.13$

.010

Step 4

ID X Joke Type X Teller Gender

.006

.04

$-.99$

.010

Note. Regression coefficients are standardized, and are from the step of variable entry.

${ }^{*} p<.05,{ }^{* *} p<.01,{ }^{* * *} p<.001$

As seen in Table 4, appraisals of the degree of sexism in the jokes were also solely influenced by joke type, in that, the jokes were appraised as more sexist $(M=3.06, S D=$ 1.24) when the jokes were group-disparaging, than when the jokes were non-disparaging ( $M$ $=0.16, S D=0.45)$. None of the remaining effects was significant.

Table 4

Summary of Hierarchical Regression Analyses for Variables Predicting Joke Sexism $(N=137)$

\begin{tabular}{ccccc} 
Predictor & $\Delta \mathrm{R}^{2}$ & $r$ & $\beta$ & $\begin{array}{r}\text { semi- } \\
\text { part } r^{2}\end{array}$ \\
\hline
\end{tabular}

Step 1

.007

ID

$-.09$

$-.09$

.007

Step 2 $.696^{* * *}$

Joke Type

$-.84 * * *$

$-.84 * * *$

$.696^{* * *}$

Teller Gender

$-.02$

.03

.001

Step 3

.009

ID X Joke Type

$-.83^{* * *} \quad .07$

.000

ID X Teller Gender

$-.03$

.60

.007 
Joke Type X Teller Gender

$$
-.52 * * * \quad-.10
$$

.003

Step 4

.005

ID X Joke Type X Teller Gender

$$
-.52 * * * \quad-.85
$$

.004

Note. Regression coefficients are standardized, and are from the step of variable entry. $* p<.05, * * p<.01, * * * p<.001$

Negative Emotions. Three hierarchical regressions were conducted to assess the effects of ingroup affect, joke type and joke-teller gender on negative emotions, namely anger, shame, and anxiety. As seen in Table 5, only joke type predicted anger, in that the group-disparaging jokes were associated with more anger $(M=2.13, S D=1.57)$ than the non-disparaging jokes $(M=0.38, S D=0.67)$. None of the remaining effects was significant.

\section{Table 5}

Summary of Hierarchical Regression Analyses for Variables Predicting Anger $(N=137)$

\begin{tabular}{lllll}
\hline Predictor & $\Delta \mathrm{R}^{2}$ & $r$ & $\beta$ & $\begin{array}{l}\text { semi- } \\
\text { part } r^{2}\end{array}$ \\
\hline
\end{tabular}

Step 1 .016

ID

$$
-.13
$$

.020

Step 2 $.338 * * *$

Joke Type

$\begin{array}{ccc}-.59 * * * & -.58 * * * & .340 * \\ .05 & .08 & .010\end{array}$

Teller Gender

.009

Step 3

$\begin{array}{lll}-.58 * * * & .27 & .002 \\ .03 & .25 & .001\end{array}$


Joke Type X Teller Gender $-.36^{* * *}-.14$

.010

Step 4 .005

ID X Joke Type X Teller Gender $-.36^{* * *} \quad-.88$ .005

Note. Regression coefficients are standardized, and are from the step of variable entry. ${ }^{*} p<.05,{ }^{* *} p<.01,{ }^{* * *} p<.001$

As with anger, joke type was a significant predictor of shame, in that the jokes were more likely to evoke shame when they were group-disparaging $(M=0.67, S D=$ $0.79)$, than when they were non-disparaging $(M=0.11, S D=0.39)$ (Table 6). Although the overall model evaluating the significance of all 32 -way interactions taken together was not significant, the joke type $\mathrm{X}$ joke-teller gender 2-way interaction was itself significant (Table 6). For exploratory purposes, the simple effects of joke-teller type were assessed, and were only found to be marginally significant in the disparaging joke condition, $F(1,69)=3.30, p=.07$, and not the non-disparaging joke condition, $F<1$. In particular, greater shame was evoked when the joke-teller was female $(M=0.85, S D=$ $0.84)$ than when it was male $(M=0.51, S D=0.71)$.

Table 6

Summary of Hierarchical Regression Analyses for Variables Predicting Shame $(N=137)$

\begin{tabular}{ccccc}
\hline Predictor & $\Delta \mathrm{R}^{2}$ & $r$ & $\beta$ & $\begin{array}{c}\text { semi- } \\
\text { part } r^{2}\end{array}$ \\
\hline Step 1 & .008 & & & \\
ID & & -.09 & -.09 & .010
\end{tabular}


Step 2

$.171^{* * *}$

Joke Type

$\begin{array}{ccc}-.41^{* * *} & -.41^{* * *} & .170^{* * *} \\ .08 & .10 & .010\end{array}$

Teller Gender

.035

Step 3

ID X Joke Type

$-.41^{* * *}$

.12

.000

ID X Teller Gender

.07

.74

.010

Joke Type X Teller Gender

$\begin{array}{lll}-.28 * * * & -.29 * & .030 *\end{array}$

Step 4

.010

ID X Joke Type X Teller Gender

$-.29^{* * *} \quad-1.25$

.010

Note. Regression coefficients are standardized, and are from the step of variable entry.

${ }^{*} p<.05,{ }^{* *} p<.01,{ }^{* * *} p<.001$

Lastly, as shown in Table 7, only joke type significantly predicted anxiety, such that group-disparaging jokes evoked greater anxiety $(M=1.29, S D=1.24)$, than did nondisparaging jokes $(M=0.31, S D=0.73)$. None of the other effects was significant.

Table 7

Summary of Hierarchical Regression Analyses for Variables Predicting Anxiety $(N=137)$

\begin{tabular}{|c|c|c|c|c|}
\hline Predictor & $\Delta \mathrm{R}^{2}$ & $r$ & $\beta$ & $\begin{array}{l}\text { semi- } \\
\text { part } r^{2}\end{array}$ \\
\hline Step 1 & .002 & & & \\
\hline ID & & -.05 & -.05 & .002 \\
\hline Step 2 & $.185^{* * *}$ & & & \\
\hline Joke Type & & $-.43 * * *$ & $-.43 * * *$ & $.180^{* * *}$ \\
\hline
\end{tabular}


Teller Gender

Step 3

ID X Joke Type

ID X Teller Gender

Joke Type X Teller Gender

Step 4
$-.01$

.01

.000

.020

ID X Joke Type X Teller Gender
$-.43 * * * \quad-.11$

.000

$-.01$

.59

.010

$-.32 * * * \quad-.21$

.010

Note. Regression coefficients are stant
${ }^{*} p<.05,{ }^{* *} p<.01,{ }^{* * *} p<.001$

Action Endorsements. Three hierarchical regressions were conducted to assess the effects of ingroup affect, joke type and joke-teller gender on collective, individual, and avoidant action endorsements. As seen in Table 8 , joke type was the only variable that predicted collective action, in that the group-disparaging jokes were associated with more collective action $(M=1.12, S D=1.28)$ than the non-disparaging jokes $(M=0.32, S D=$ 0.85). Neither the 2-way interactions between ingroup affect and the manipulated humor variables, nor their 3-way interaction was significant.

Table 8

Summary of Hierarchical Regression Analyses for Variables Predicting Collective Action $(N=137)$

Predictor

Step 1

ID

$$
\Delta \mathrm{R}^{2}
$$

$r$

$\beta$

semipart $r^{2}$
.002

$-.04 \quad-.04$

.001 
Step 2

Joke Type

Teller Gender

Step 3

ID X Joke Type

ID X Teller Gender

Joke Type X Teller Gender

Step 4

ID X Joke Type X Teller Gender
$.118^{* * *}$

$-.34 * * * \quad-.35 * * * \quad .110^{* * *}$

.02

.04

.001

.003

$\begin{array}{lcc}-.34 * * * & .26 & .001 \\ .02 & .29 & .002 \\ -.19 * & -.01 & .000\end{array}$

.002

.62

.003

Note. Regression coefficients are standardized, and are from the step of variable entry. $* p<.05, * * p<.01, * * * p<.001$

Similar to collective action, only joke type significantly predicted individual action endorsements (Table 9), in that the jokes were associated with more individual action when they were group-disparaging $(M=0.64, S D=0.80)$, than when they were non-disparaging ( $M=0.15, S D=0.49)$. None of the 2-way interactions nor the 3-way interaction significantly influenced individual action endorsements.

Table 9

Summary of Hierarchical Regression Analyses for Variables Predicting Individual Action $(N=137)$

\begin{tabular}{ccccc}
\hline Predictor & $\Delta \mathrm{R}^{2}$ & $r$ & $\beta$ & $\begin{array}{r}\text { semi } \\
\text { part } r\end{array}$ \\
\hline Step 1 & .002 & & & \\
ID & & .05 & .05 & .003
\end{tabular}


Step 2

$.131^{* * *}$

Joke Type

$\begin{array}{ccc}-.35^{* * *} & -.36^{* * *} & .130^{* * *} \\ .05 & .07 & .004\end{array}$

Teller Gender

.005

Step 3

ID X Joke Type

$\begin{array}{lrl}-.34^{* * *} & -.35 & .002 \\ .06 & .33 & .002\end{array}$

Joke Type X Teller Gender

$-.18^{*}-.02$

.000

Step 4

.000

ID X Joke Type X Teller Gender

$-.17^{*}$

.18

.000

Note. Regression coefficients are standardized, and are from the step of variable entry. ${ }^{*} p<.05,{ }^{* *} p<.01,{ }^{* * *} p<.001$

Although ingroup affect did not predict avoidant endorsements (Table 10), the manipulated humor variables did influence such endorsements. Once again, only joke type was significant, such that disparaging jokes were associated with more avoidant action endorsements $(M=2.47, S D=1.71)$ than were non-disparaging jokes $(M=1.31, S D=1.53)$. None of the 2-way interactions nor the 3-way interaction significantly influenced avoidant endorsements. 
Table 10

Summary of Hierarchical Regression Analyses for Variables Predicting Avoidant

Endorsements $(N=137)$

\begin{tabular}{ccccc} 
Predictor & $\Delta \mathrm{R}^{2}$ & $r$ & $\beta$ & $\begin{array}{r}\text { sem } \\
\text { part }\end{array}$ \\
\hline Step 1 & .002 & & & \\
ID & & -.05 & -.05 & .000
\end{tabular}

Step 2

$.113^{* * *}$

Joke Type

$-.34 * * * \quad-.34 * * * \quad .112 * * *$

Teller Gender

$-.03$

$-.01$

.000

Step 3

.028

ID X Joke Type

$-.32^{* * *}$

1.01

.020

ID X Teller Gender

$-.03$

.10

.000

Joke Type X Teller Gender

$-.16^{*}$

.15

.006

Step 4

.001

ID X Joke Type X Teller Gender

$-.15^{*}$

.44

.001

Note. Regression coefficients are standardized, and are from the step of variable entry. ${ }^{*} p<.05,{ }^{* *} p<.01,{ }^{* * *} p<.001$

\section{Mediation Analyses}

As shown in Figure 1, a mediated model was hypothesized, wherein anger was expected to mediate the relation between joke appraisals and collective action endorsements. Shame and anxiety were also hypothesized to mediate joke appraisals and avoidant or individual endorsements (Figure 2). A mediated model was only regarded as viable when (1) 
the predictors (joke funniness or joke sexism appraisals) were significantly related to the mediating variables (anger, shame, or anxiety), (2) the predicators were significantly related to the outcome variables (collective, individual, or avoidant endorsements), and (3) the mediating variables (that were related to the predictors) were also related to the outcome variables (Baron \& Kenny, 1986). These criteria resulted in the examination of six multiple mediation models, wherein the two joke appraisals (funniness and sexism) each served as predictors, of the three action endorsements (collective, individual, or avoidant), with each hypothesized relation potentially mediated by certain emotions (anger, shame, or anxiety). It is important to note that since shame was not found to be significantly related to joke funniness (Table 1), only anger and anxiety were examined as potential mediators in the link between joke funniness and all of the action endorsements. The bootstrapping option was used to assess the significance of the indirect paths. Full mediation was deemed to exist if the direct path between appraisals and action endorsements was not significant when the effects of negative emotions were controlled, and the indirect path through emotions was significant.

The mediating role of negative emotions between joke appraisals and collective action endorsements. In assessing the emotion variables mediating the relation between joke funniness and collective action, the direct effects of joke funniness on action were not reduced to nonsignificance with the mediating role of emotions controlled. As shown from the bias corrected confidence intervals for anger, partial mediation between joke funniness and collective action was supported. The indirect effects of anxiety were not significant (Table 11).

Consistent with a mediation model, the direct effects of joke sexism on collective action were reduced to nonsignificance with the mediating role of emotions controlled. 
Examination of the unique mediational effects of each of the three emotions (based on confidence limits not containing zero) suggested that the higher levels of anger experienced when a joke was perceived as sexist served to mediate the relation between joke sexism and stronger collective action endorsements (Table 11). The indirect effects of shame and anxiety were not significant.

Table 11

Summary of Multiple Mediation Analyses involving Appraisals and Collective Endorsements

$\begin{array}{llcc}\text { Total } & \text { Direct } & \text { Indirect } & \text { BC Bootstrap } \\ \text { Effect } & \text { Effect } & \text { Effects } & \underline{95 \% \mathrm{CI}}\end{array}$

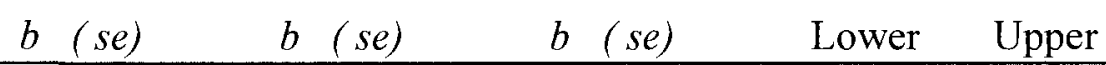

Funniness Appraisal

Total

$$
\begin{array}{rrrr}
-0.53(0.06)^{* * * *}-0.32(0.06)^{* * *}-0.21(0.05) & -0.324 & -0.118 \\
& -0.13(0.06) & -0.265 & -0.019 \\
& -0.08(0.06) & -0.225 & 0.018
\end{array}
$$

Anger

\begin{tabular}{|c|c|c|c|c|}
\hline Total & $0.35(0.05)^{* * *} \quad 0.02(0.07)$ & $0.32(0.08)$ & 0.175 & 0.509 \\
\hline Anger & & $0.22(0.09)$ & 0.051 & 0.414 \\
\hline Shame & & $-0.05(0.04)$ & -0.129 & 0.017 \\
\hline Anxiety & & $0.15(0.07)$ & -0.001 & 0.315 \\
\hline
\end{tabular}

Anxiety

Sexist Appraisal 
The mediating role of negative emotions between joke appraisals and individual action endorsements. When the entry of anger and anxiety were controlled for, the multivariate direct effect of joke funniness on individual action remained significant. As shown from the bias corrected confidence intervals for anxiety, partial mediation between joke funniness and individual action was supported. However, the indirect effects of anger were not significant (Table 12).

The direct effects of appraisals of sexism on individual action were reduced to nonsignificance with the mediating roles of all three emotions were controlled. Furthermore, as shown in Table 12, the indirect path through emotions on individual action was significant. Examination of the unique meditational effects of these emotions indicated that higher levels of anger and anxiety experienced when a joke was appraised as sexist served to mediate the link between joke sexism and stronger individual action (Table 12). The indirect effects of shame were not significant.

Table 12

Summary of Multiple Mediation Analyses involving Appraisals and Individual Endorsements

\begin{tabular}{|c|c|c|c|}
\hline Total & Direct & Indirect & BC Bootstrap \\
\hline Effect & Effect & Effects & $95 \% \mathrm{CI}$ \\
\hline (se) & $b \quad(s e)$ & $b \quad(s e)$ & Lower \\
\hline
\end{tabular}

Funniness Appraisal

\begin{tabular}{lllll} 
Total & $-0.26(0.04)^{* * *}-0.09(0.03)^{*}$ & $-0.17(0.04)$ & -0.257 & -0.100 \\
Anger & $-0.06(0.03)$ & -0.130 & 0.006 \\
Anxiety & $-0.11(0.04)$ & -0.200 & -0.038 \\
\hline
\end{tabular}


Sexist Appraisal

Total

$0.24(0.03)^{* * *} 0.04(0.04)$

$0.20(0.04)$

0.132

0.304

Anger

$0.08(0.04) \quad 0.001$

0.173

Shame

$-0.02(0.02) \quad-0.062$

0.031

Anxiety

$0.14(0.05)$

0.061

0.251

$* p<.05 ; * * * p<.001$

The mediating role of negative emotions between joke appraisals and avoidant

endorsements. Because shame was not significantly associated with joke funniness at the correlational level, only anxiety and anger were viable mediators. The direct effects of joke funniness on avoidance were not reduced to nonsignificance with the mediating role of anger and anxiety controlled (Table 13). Indeed, an examination of the unique mediational effects of the emotions suggested that neither full, nor partial mediation was supported.

As expected, the direct effects of perceived sexism on avoidant endorsements were reduced to nonsignificance when the indirect paths through emotions were controlled, and the indirect path through emotions on avoidant endorsements was significant (see Table 13). An examination of the unique mediational effects of each of the three emotions suggested that, consistent with expectations, the higher levels of anxiety experienced mediated the relation between appraisals of sexism and stronger avoidant endorsements, whereas the indirect effect of anger was not significant. As for the indirect effects of shame, the bootstrapped confidence limits indicated that mediation between joke sexism and avoidant endorsements was supported; however the path from shame to avoidant endorsements was unexpectedly negatively related, suggesting it served more in a suppressor, rather than 
mediation role.

Table 13

Summary of Multiple Mediation Analyses involving Appraisals and Avoidant

Endorsements

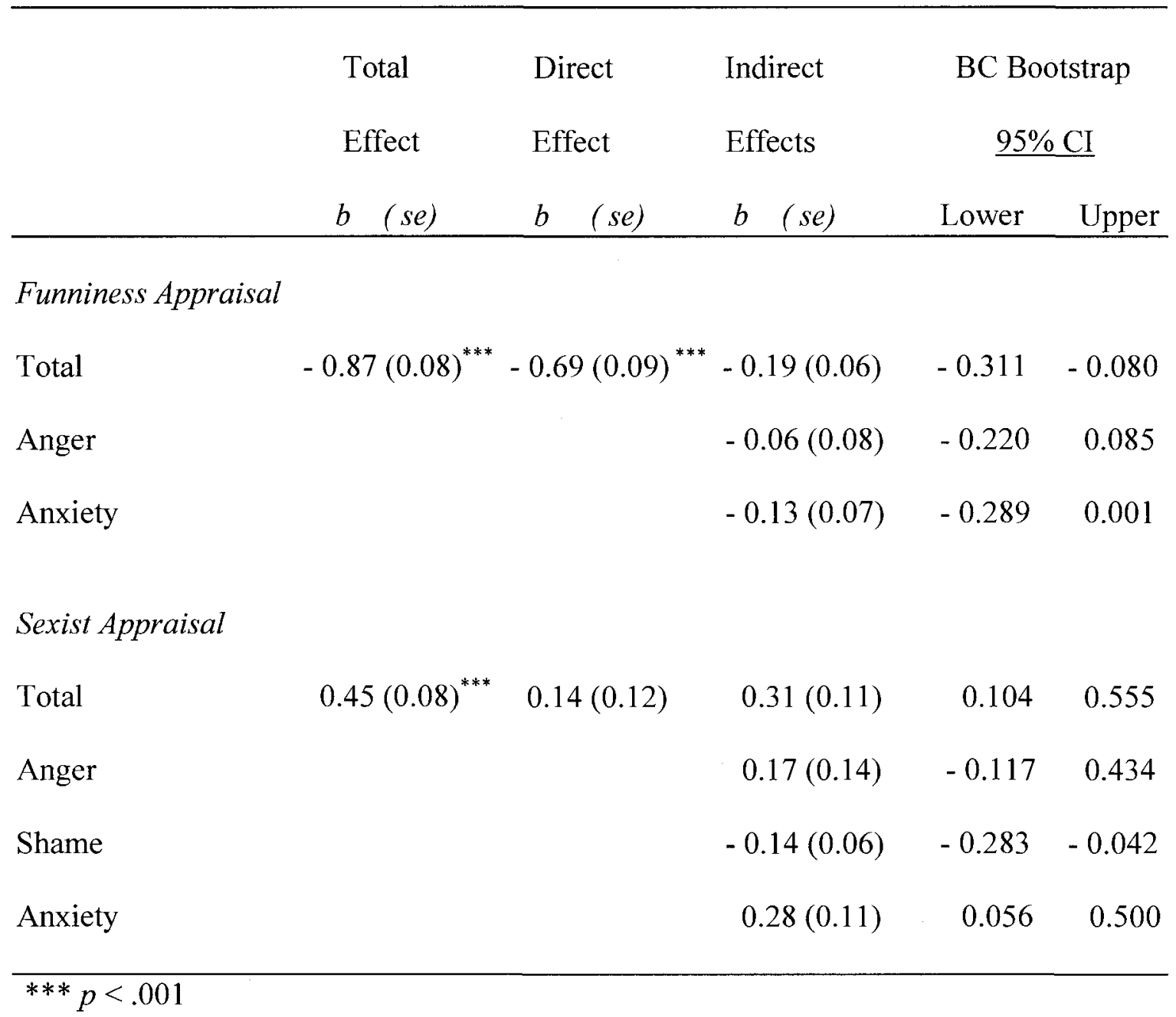

Discussion

Although research focusing on the beneficial aspects of humor is extensive (e.g.,

Cogan, Cogan, Waltz, \& McCue, 1987; Kazarian \& Martin, 2004; Martin, Kuiper,

Olinger, \& Dance, 1993; McGhee, 1999; Overholser, 1992), the potential negative effects 
of group-based humor have been seldom explored. The present study sought to explore how intergroup processes may contribute to the interpretation of humor targeted toward particular groups, and in particular toward women. Specifically, when exposed to jokes, the type of joke, the gender of the joke-teller and the degree to which individuals (in the present study, females) identified with their own gender were deemed to be especially important to the interpretation of jokes in the intergroup context. A positive relation between females' negative appraisals and behavioural reactions was expected, and moreover, their emotional reactions were expected to mediate these responses to jokes. When a joke-teller is male, it was hypothesized that, particularly among high identifying females, disparaging jokes would be interpreted more negatively than if a member of the ingroup (a woman) told the same disparaging jokes. This overall hypothesis was not supported. Only the type of joke, that is, disparaging relative to nondisparaging jokes, differed across females' perceptions of jokes. In particular, females perceived disparaging jokes as equally less funny, and more offensive, aggressive and sexist, regardless of who told the jokes or how much they identified with their gender.

That the joke-teller did not influence appraisals and emotions reactions was surprising. According to social identity theory, ingroup members tend to view their own members more positively than outgroup members, and this is especially the case for highly identified ingroup members (Jetten et al., 2002; Tajfel \& Turner, 1979). In particular, comments that originate from the outgroup might be interpreted as being untruthful, having ill-intent, and being discriminatory; however, the same comments told by an ingroup member are more likely to be interpreted as constructive criticism, and thought to encourage positive forward-thinking about the ingroup's status. In this light, 
women were expected to evaluate the female joke-teller more positively than the male joke-teller. Indeed, according to work by Hornsey and colleagues (e.g., Hornsey et al., 2005; Hornsey, Trembath, \& Gunthorpe, 2004) the ingroup critic (or derogatory joketeller in the present case) is viewed positively compared to critics from an outgroup. Ingroup critics are cast in a relatively positive light because it is assumed they are doing so for the betterment of the group (i.e., shed light on issues the ingroup is currently facing). Within the context of the present study, however, this ingroup bias was not observed.

One possible explanation for why an effect of joke-teller was not observed comes from research on the black sheep effect (Marquez \& Paez, 1994), wherein undesirable or misbehaving ingroup members are psychologically distanced from the group. Within this context, the woman joke-teller might have been evaluated negatively because her jokes were perceived as abnormal and unwelcome. If such were the case, the lack of differentiation between the male and female joke-teller might have been the result of the female being evaluated in a similar negative light as the male joke-teller. Although the black sheep effect is speculative, these appraisals may more likely be indicative that the manipulation of joke type or joke-teller gender, or the measurement of gender identification might be called into question, which will be discussed in turn.

It was also anticipated that when a man told disparaging jokes, high identifying females would be especially likely to express anger - an emotion expressed when the outgroup is viewed as responsible for negative ingroup treatment (Pennekamp et al., 2007). On the other hand, low identifying females were expected to respond to disparaging jokes told by a man with more shame, an emotion associated with 
uncontrollability and personal weakness related to one's group membership (Branscombe et al., 2004; Lickel et al., 2004) or anxiety, an emotion relating to uncertainty or a lack of control over the negative event. Again, no support was found for these combined hypotheses. In line with predictions, however, the type of joke (i.e., disparaging relative to non-disparaging) was related to differences in females' emotional reactions to jokes. Specifically, when jokes targeted their gender, females expressed more anger, shame and anxiety compared to non-disparaging jokes. Thus, in spite of who told the jokes, or their level of gender identification, females' reacted to disparaging jokes with a range of negative emotions. Contrary to appraisal theories of emotion (Frijda, 1986; Roseman, 1984) and past research (Mackie et al., 2000), females in the present study expressed an outgroup emotion (anger) toward an ingroup member. Moreover, the only emotion that seemed to be related to both joke type and joke-teller gender was shame. Unexpectedly, females reported more shame in response to disparaging humor that originated from a woman (i.e. self-deprecating humor) and not a man (i.e. repressive humor).

It is possible that females might feel ashamed or embarrassed when another woman degrades their group, and that the woman's jokes do not generally fit with the group's prototypical goals (Schmitt \& Branscombe, 2001). Perhaps linked to this, these unexpected emotional reactions toward members of their own group may be related to a joke or set of jokes that were initially developed by a man, thus indicating that in actuality, self-disparaging jokes told by a woman differ in content from what an outgroup member would say. Furthermore, because shame was the only variable to show such an effect in relation to joke type and joke-teller gender, this finding may be due to a spurious interaction between the humor variables and thus merits replication to establish if true 
effects exist. Future research should also examine the potential differences among disparaging joke types. Additionally, as with the appraisal of disparaging jokes and uncommon findings in relation to past research, emotional reactions and the manipulation of joke type or joke-teller gender and the measurement of gender identification will be discussed in turn.

It was also expected that when disparaging jokes were told, high identifying females would be more likely to endorse collective action toward a male but not a female joke-teller. In contrast, low identifying females were expected to endorse more individualistic or avoidant actions when a man told disparaging jokes, but not when a woman did. Once more, this overall hypothesis was not supported. That said, disparaging relative to non-disparaging jokes were related to differences in females' action endorsements. When jokes targeted their gender, females endorsed more collective, individual, and avoidant behaviours compared to non-disparaging jokes. These findings suggest that aside from joke-teller gender and gender identification, females' reacted to disparaging jokes with a range of action endorsements.

Indeed, the suggestion that females endorsed collective behaviour toward another member of their group is inconsistent with most research, particularly since such actions are generally intended to defend the ingroup's status (Doosje et al., 1995; Jetten et al., 2002). Individual action or avoidant behaviour may not be overly surprising, but only among low identifiers, which was not demonstrated in the present study. Instead, the ingroup typically accepts or tolerates ingroup criticism, since as mentioned earlier; they believe that criticism is said for the good of the group (Hornsey et al., 2005; Hornsey et al., 2002). One exception to this, however, might include if the ingroup joke-teller is 
thought to be purposely distancing herself from other women, or if the woman is a newcomer to the group. In this case, other females might be less tolerant and in some cases, remove and dissociate themselves from group members that look bad for the group (Hornsey, 2005; Marques \& Paez, 1994). It is feasible that participants perceived the ingroup member as trying to distance herself from or mock the ingroup. If that were the case, female participants would be expected to be equally intolerant of her joke-telling as compared to the male joker-teller. It is also possible that although a female comic was perceived as a "newcomer" comic at the University. In this way, the degree of social identification at play here may extend beyond gender, and perhaps into other social identities, namely as a student at the University. Without having measured this type of identity, however, it is difficult to confirm if this is how females would actually respond to a newcomer comic on campus.

Finally, another reason that females endorsed all actions might be related to their ability to access resources to carry through certain behaviours. According to Ajzen (1988; 1991), the less contingent behaviour is on internal or external resources, the more likely that behaviour will be perceived to be under a person's control. Thus, if individuals perceive that they can freely decide to either perform or not perform a particular behaviour, then they may be more likely to endorse certain behaviours without fear of being criticized or reprimanded for their actions. Certainly, the females in the present study were not asked about whether they thought their actions would negatively impact their social identity. Instead, the comic evaluation surveys empowered the students to decide if the prospective comic should perform on campus, and furthermore, requested that they report back to their university student association on their decision. Therefore, 
when given the ability to choose the fate of the comic, as well as the use the campus resources (i.e. student-run university association, student-run radio station) to make such decisions, females in the present study may have willingly endorsed many of the actions without fear of reprisal.

Common features among appraisals, emotions, and action endorsements

In relation to all appraisals, emotions, and actions endorsed on behalf of the females in the current study, the lack of support for joke-teller gender might lie in the overall strength of its manipulation, as well as the manipulation of other variables such as the delivery of joke content. In particular, the only references to gender included a picture and gender-specific name assigned to either a male or female joke-teller on paper comic evaluation handouts. Although joke-teller gender was supported by a manipulation check, as well as successfully employed in past humor research (e.g. in written format such as with the work of Bill and Naus (1992); Ford (2000); Ryan and Kanjorski (1998); and Thomas and Esses (2004), or in cartoon format with the work of Love and Deckers (1989); and Moore, Griffiths, and Payne (1987)), alternative methods of evaluating joketeller gender might have proved to enhance the salience of joke-teller gender. Other humor studies have used audio recordings (e.g. Greenwood \& Isbell, 2002; LaFrance \& Woodzicka, 1998), and more recently, video clips (Ford, Boxer, Armstrong \& Edel , 2008) to convey joke-teller gender to their audience. Even though these latter methods of delivering jokes may have strengthened the salience of joke-teller gender, the addition of audio and visual cues might come at a cost. For example, the use of audio recordings or video clips could potentially introduce numerous other confounding variables, including the influence of the joke-teller's tone of voice and delivery of jokes. This being said, it is 
possible that, in reality, the tone and delivery of jokes differs between males and females, and differs when one tells a repressive or a self-disparaging joke.

An audio or video recording might also allow for a laugh track or canned audience laughter. Such an inclusion might increase participants' immersion into the task. Although canned laughter might add a dimension of reality to the experience of evaluating comedians, hearing other ingroup or outgroup members laughing might influence an individual's perception of humorous content (Lawson, Downing, \& Cetola, 1998; Platow, Haslam, Both, Chew, Cuddon et al., 2005). For instance, jokes were perceived as less funny and less amusing when outgroup laughter was heard, but the opposite was true for ingroup laughter. Additionally, attributions about the general physical appearance of the joke-tellers in video clips might also need to be controlled for. For example, physical attractiveness on behalf of the joke-teller (Ambady \& Rosenthal, 1993), as well as subtle facial expressions (Knutson, 1996) might favourably influence participants' evaluations of their jokes relative to less attractive joke-tellers and unappealing facial expressions on behalf of the joke-teller.

Although it is possible that the salience of joke-teller gender was not sufficient to elicit appraisal differences in the present study, it is also possible that the gender of the source of jokes does not matter. Among females in this study, perhaps joke-teller gender has little or no impact on how group-disparaging jokes are appraised, nor is it differentially associated with the ability to emotionally upset or lead females to endorse a different set of behaviours. Overall, the lack of support for joke-teller gender as an influence on appraisals, emotions, and action endorsements is more likely due to the 
suggested weakness among joke delivery and joke-teller gender manipulation, and not as a contradiction to the vast research on intergroup processes on responses to criticism.

\section{Group Identification and Responses to Humour}

Numerous studies have suggested that the extent to which individuals identify with their social group may influence how they respond to identity threats (Jetten, Postmes, \& McAuliffe, 2002; Jetten, Spears, \& Manstead, 1997). Yet, in the present study, strength of gender identification did not alter women's responses to the disparaging jokes.

Although gender identification can be examined as an overall construct, it has also been measured as a multidimensional construct. According to Cameron (2004), the three dimensions of group identification (affect, centrality, and in-group ties) are typically correlated with one another, especially ingroup affect and ingroup ties, as these dimensions are both related to emotional facets of social identity. Among the females in the present study, only ingroup ties and centrality were mildly related to one another and neither was related to ingroup affect. This finding suggests that females in the study felt only somewhat connected with other females and viewed their gender as an important part of their identity, however, these evaluations did not relate to how proud they felt about their gender, or whether they held positive or negative attitudes toward their gender. It may be recalled that ingroup affect was quite high among females in the present study (both in the mass-testing and post-experimental measure), suggesting that the females held positive emotional evaluations toward their gender. If this were the case, then females might be more inclined to view a female joke-teller's disparaging jokes in a 
positive light, and essentially, demonstrate an ingroup bias (Hornsey et al., 2002; Jetten \& Spears, 2003; Jetten et al., 2002; Tajfel \& Turner, 1979).

That this ingroup bias was not found was surprising. It could be that despite their positive evaluations of their gender, some females may have attributed the negative feedback to the joke-teller's own prejudice and not to their own weakness (Crocker \& Quinn, 1998). Furthermore, it could be that the female joke-teller's behaviour was not stereotypical of the ingroup but rather the outgroup, and thus females were upset and were more likely to reject her disparaging jokes. In line with this, females in the present study may have had higher stigma consciousness, that is, they generally expect to be negatively stereotyped (Brown \& Pinel, 2003; Pinel, 2002), but not by a member of their own group. Furthermore, the disparaging jokes may have more likely tapped into old-fashioned sexism, that is, that women are generally incompetent, and consequently, the jokes may have been interpreted as more deliberate and blatantly sexist, rather than ambiguous and subtle (Swim, Aiken, Hall, \& Hunter, 1995; Swim, Hyers, Cohen, \& Ferguson, 2001). Thus, females may have expected such jokes to come from a man, but not from another woman, which may be why there was no differentiation between their responses to disparaging humor.

The lack of moderating influence may also be related to how gender identification scores were compiled and measured in the present study. Acknowledged earlier, the recruitment issues encountered in this study, and ultimately the integration of mass testing data with post-manipulation session data may have certainly complicated the interpretation of gender identification as a moderating variable in later analyses. Although statistical tests supported the integration of gender identification data, using only the mass 
testing sample's gender identification scores $(n=44)$ would have severely compromised statistical power of the tests performed in the present study. ${ }^{4}$

In sum, this is not to say that gender identification (or any of its respective dimensions) is not an important social variable and moderator, but perhaps under more scrupulous data collection conditions, the true relationships between gender identification and the other variables might have been better elucidated. Furthermore, the fact that joketeller gender made no difference to females' appraisals and emotional or behavioural reactions to jokes perhaps indicates that intergroup processes may not have been at play at all. In this way, gender identification would also not be relevant, since this variable is crucially linked to whether or not the person telling jokes targeting women is an outgroup (man) or an ingroup (woman) member. Rather, the lack of support for gender identification in the present study may be more aligned to the strength of manipulation of joke-teller, as well as joke type, instead of a reflection of no intergroup processes.

\section{Interpretation and Reactions to Disparaging Humor}

According to social identity and humor research, insofar as certain jokes are interpreted as threats to identity, the strength of these appraisals would be related to particular emotional and behavioural reactions in ingroup members (Frijda, 1986; Smith \& Ellsworth, 1985; Pennekamp et al., 2007; Roseman, 1984). In the present study, the type of joke, and in particular those that were derogatory to women, was found to influence females' appraisals and emotional and behavioural reactions.

Consistent with previous work (La France \& Woodzicka, 1998; Mackie et al., 2000; Matheson \& Anisman, 2008; Stangor \& Crandall, 2003; van Zomeren et al., 2004), comments or jokes that derogate the ingroup were related to perceived threat and also to 
specific emotions. As demonstrated in the present study, joke sexism was related to all negative emotions of interest, namely anger, shame, and anxiety, whereas joke funniness was related to anger and anxiety. Joke funniness was unrelated to shame; however, this perhaps reflects that finding disparaging jokes less humorous did not lead females to feel ashamed or that their evaluations of such jokes were their fault. This possibility is likely as females voluntarily participated in a study that asked them to evaluate jokes by a prospective comic. Further, the study's findings on females' joke appraisals may outline the relevance of particular joke appraisals and their strength in determining threat, and subsequently, responses to jokes as threats. In particular, appraisals of joke sexism might be more relevant to the perception of threat than were appraisals of joke funniness; since the perception of prejudice against one's female identity is more personally threatening (Major, 2006) than would a general lack of appreciation or enjoyment of demeaning jokes. Sexist appraisals are thus more likely to be associated with anger and assigning blame toward the disparager, and anxiety and feelings of uncontrollability and ambiguity toward the disparager (Dan et al., 1995; Paludi \& Barickman, 1991; La France \& Woodzicka, 1998, 2001). However, appraisals of joke funniness are still of value, as this demonstrates that disparaging, and in particular sexist jokes are viewed as less funny than was shown in earlier studies (Cantor, 1976; Losco \& Epstein, 1975; Zillmann \& Cantor, 1976).

Relation between appraisals and action endorsements. Females' appraisals of disparaging jokes were less funny and more sexist, and moreover, these appraisals were related to the endorsement of collective, individual, and avoidant actions toward the disparager. Particularly, females' perceived sexism and lack of joke funniness was 
related to all action endorsements. Certainly, with regard to appraisals of joke funniness, if jokes are not funny to women, and the intent is to have a comedian perform on campus for the students, then women would not want to attend the event. As for the endorsement of collective or individual actions, females' appraisals of joke unfunniness may have been related to their own ability to have power over who should perform on campus and possibly their own sense of humor. Specifically, perhaps females would rather take any action to ensure that an unfunny comedian does not come to campus, or they may endorse behaviour such as heckling to communicate their own sense of humor to the joke-teller (Wagg, 1998).

As for reactions to perceived joke sexism, females' endorsements of collective, individual and avoidant behaviour are likely tied to the underlying threat elicited by disparaging jokes. Indeed, research has shown that sexist jokes or comments are often perceived as threatening to women, and moreover, the extent of perceived threat may lead females to take different courses of action in response to the threat (La France \& Woodzicka, 2001, Swim \& Hyers, 1999).

\section{Mediating role of emotions}

Consistent with appraisal theories of emotion (Frijda, 1984; Roseman, 1984; Smith \& Ellsworth, 1985) and behavioural antecedents related to such appraisals of identity threat (Hercus, 1999; Mackie \& Smith, 2004; Wright, Taylor, \& Moghaddam, 1990), females did perceive disparaging jokes as less funny and more sexist, and were more likely to express more anger, shame, and anxiety, and to endorse collective, avoidant, and individualistic action relative to non-disparaging jokes. 
Research on intergroup emotions has found that certain emotions mediated perceptions of social identity threat and action endorsements (Johns, Schmader, \& Lickel, 2005; Mackie et al., 2000; van Zomeren et al., 2004). For instance, Mackie, Devos and Smith (2000) found that among ingroup members who perceived their group as strong, they were more likely to experience anger toward a disparaging outgroup, and also more to take offensive actions toward the outgroup. In line with this research, when disparaging jokes were appraised as both less funny and sexist, higher reports of anger were associated with the likelihood to take collective action against the joke-teller's performance. It is important to note, however, that reduced joke funniness and collective action was only partially mediated by anger, whereas joke sexism and collective action was fully mediated by anger. One reason for this incomplete mediation might indicate that the main emotion involved may be something other than anger. For instance, finding someone's jokes to be generally unfunny may not chiefly elicit anger, but perhaps contempt (Roseman, 1996). Given this line of thought, having contempt or extreme dislike toward the joke-teller might have best explained why females endorsed collective action.

In contrast, perceived sexism has been consistently associated with both anger and the likelihood to take collective action (Hercus, 1999; LaFrance \& Woodzicka, 1998; Pennekamp, Doosje, Zebel, \& Fischer, 2007). The present study's findings demonstrate that when disparaging jokes are perceived as threats to females' social identity, females are more likely to express anger, and also more likely to endorse collective actions to contend with the threat. 
Regarding individual action, when females perceived disparaging jokes as less funny and more sexist, higher anxiety led to a greater likelihood that they would take individual action toward the joke-teller's impending performance on campus. Although anxiety is typically associated with avoidant behaviour in response to perceived threat, these findings are in line with research that views anxiety as an emotion that has a preparatory function, which may in turn motivate individuals to take action to contend with threat (Calvo \& Eysenck, 2000; Mogg, McNamara, Powys, Rawlinson, et al., 2000). Similar to the previous mediation model joke funniness, anxiety only partially mediated reduced funniness and individual actions; again perhaps suggesting that other emotions (i.e. contempt) may be more related to the perceptions of joke funniness.

With regard to sexist appraisals, females' anger also explained their appraisals of disparaging jokes and their likelihood to take individual action. Consistent with research, when people appraise a situation as discriminating or threatening, anger is experienced, and moreover, their intent to contend with the situation is influenced by anger (Mackie et al., 2000, van Zomeren et al., 2004). The influence of anxiety and anger on perceived joke sexism and individual action might also be the result of co-occurrence of anxiety with anger (or vice-versa). In particular, past research has found that even though one emotion is more likely to be experienced in response to identity threat (i.e. anger), others may also be experienced at the same time (Tangney \& Dearing, 2002; Tracy \& Robins, 2004).

Finally, pertaining to avoidant endorsements, mixed results were obtained in the present study. Finding jokes less funny and the likelihood of avoiding the comedian's performance were not explained by negative emotion; however, the opposite was true for perceived joke sexism. In line with research, when females perceived jokes as sexist, they 
were more likely to avoid the situation, which was explained by anxiety (Kaiser \& Miller, 2004). For instance, this chain of responses may be particularly linked to appraising disparaging jokes as threatening, and in turn, fostering beliefs of personal uncertainty and uncontrollability, which promote anxiety and avoidant behaviour. Shame also explained females' appraisals of joke sexism and endorsement of avoidant actions. In this sense, females may have perceived that the disparaging jokes reflected personal weaknesses relating to their own group membership which were beyond their control, thus females were more likely to avoid or distance themselves from the joke-teller's performance (Johns, Schmader \& Lickel, 2005; Matheson \& Anisman, 2008). Contrary to predictions, however, shame was negatively associated with avoidant endorsements in the mediated model. In this case, shame may have been suppressing the effects of joke sexism on avoidant endorsements when it is entered as a mediator. The co-occurrence of anxiety with shame may also be suppressing one another (Paulhus, Robins, Trzesniewski, \& Tracy, 2004).

\section{Limitations}

The present study has several limitations. First and foremost, most of the measures used in this study were constructed to reflect a realistic scenario that students might encounter on campus. In fact, all of the scales of interest, excluding gender identification (Cameron, 2004), were developed and used for the first time with this study in mind. Although considerable research and piloting was performed to validate the measures of interest, the generalizability of the study findings is questionable. Specifically, the distinction between disparaging joke types (repressive versus selfdeprecation) may not have been distinguished well enough. This may have impacted 
females' responses to the jokes, as well as omitted the possible interpretation that jokes told by a woman might also be positive. For example, the manipulation check item linked to identifying self-deprecating humor might have been better worded as 'the comic was self-critical' or 'ironic' and not with as 'hypocritical or two-faced', which may have displayed a negative connotation.

Furthermore, the actual disparaging joke stimuli used in the present study may be brought into question. Although these jokes were for the most part intended to be told by either a man or a woman, they may be attributed as mainly male-derived jokes, and less aligned with jokes that are told by women, which sometimes have more of a selfdisclosing narrative (Lampert \& Ervin-Tripp, 1998). Future research should examine the subtleties and commonalities of male and female humor to determine whether or not the same disparaging jokes can be told the same way by either a man or woman.

Next, it is also possible that the context in which the study took place may not be translated to a real-life setting. Given that participants read jokes in a laboratory setting, and not through the use of audio or visual aids, or even at an actual comedy club, females' reactions may have differed and moreover, joke teller gender and identification differences might be elicited in a different context.

It is also important to note that the actions that females endorsed in this study may not translate to actual responses to sexist jokes. As shown by the work of LaFrance and Woodzicka (2001) and Swim and Hyers (1999), females' responses to hypothetical events involving sexism do differ from their actual actions. Therefore, the study's findings in terms of endorsed actions should only be interpreted as tendencies to do certain acts and not a true reflection of their behaviour. 
Finally, the gender of the experimenter may have influenced social desirability thereby diminishing the effects of joke-teller gender and gender identification. In the present study, a female experimenter administered all sessions. It is possible that a female presence increased the role of social desirability on how women responded. Specifically, females may have rated disparaging jokes more negatively in order to be viewed more favourably by the experimenter.

\section{Implications and General Conclusion}

The present study findings indicated that joke type differentially affected females' interpretation and emotional and behavioural reactions to jokes. In particular, females perceived jokes that demeaned women as less funny and more sexist, expressed more anger, shame and anxiety, and endorsed more collective, individual, and avoidant actions relative to non-disparaging jokes. Specific emotions were found to mediate the relation between appraisals and behavioural reactions to disparaging jokes. Of particular relevance to previous research, anger explained the relation between females' negative joke appraisals and collective action endorsements toward the joke-teller's performance. Anxiety also mediated females' negative joke appraisals and individual action endorsements toward the joke-teller's performance. Finally, shame and anxiety both explained the link between females' perceived joke sexism and avoidant endorsements toward the joke-teller's performance. The study's findings are important because they, in part, shed light on the psychological process - that is, the relation between thought, emotion, and behaviour - involved in interpreting disparaging humor. Although the effects of joke-teller gender and gender identification as a woman were not shown to influence females' appraisals, emotions, and behavioural reactions to jokes in the present 
study, these findings do not suggest a true lack of intergroup processes involved in the interpretation of humor, but rather a reflection of manipulation weakness, and methodological issues, as well as an invitation for further research. Understanding how humor is appraised, and subsequently how it impacts our emotions and behaviours may also be important to consider when using humor to introduce new products or merchandise in the consumer marketing industry or other areas of mass media.

Overall, even if jokes are intended to make individuals laugh, reduce negative affect, and bring people together, jokes that undermine women may instead be interpreted in the opposite way. Such jokes can be taken as threats and also emotionally upset targeted individuals and furthermore, create disagreement or greater distance between people (Lynch, 2002; Meyer, 2000; Fine \& De Soucey, 2004). 


\section{References}

Abrams, D., \& Hogg, M. A. (1990). Social identity theory: Constructive and critical advances. New York: Springer-Verlag.

Ambady, N., \& Rosenthal, R. (1993). Half a minute: Predicting teacher evaluations from thin slices of nonverbal behavior and physical attractiveness. Journal of Personality and Social Psychology, 64, 431-441.

Baron, R.M., \& Kenny, D.A. (1986). The moderator-mediator variable distinction in social psychological research: Conceptual, strategic, and statistical considerations. Journal of Personality and Social Psychology, 51(6), 1173-1182.

Barnes, B., Palmary, I., \& Durrheim, K. (2001). The denial of racism: the role of humor, personal experience, and self-censorship. Journal of Language and Social Psychology, 20, 321-338.

Bill, B., \& Naus, P. (1992). The role of humor in the interpretation of sexist incidents. Sex Roles, 27, 645-664.

Branscombe, N. R., Slugoski, B., \& Kappen, D. M. (2004). The measurement of collective guilt: What it is and what it is not. In N. R. Branscombe, \& B. Doosje (Eds.), Collective guilt: International perspectives. New York: Cambridge University Press.

Brown, R. (2000). Social Identity Theory: Past achievements, current problems and future challenges. European Journal of Social Psychology, 30, 724-778.

Brown, P., \& Levinson, S. C. (1987). Politeness: Some universals in language usage. New York, NY, US: Cambridge University Press. 
Brown, R. P., \& Pinel, E. C. (2003). Stigma on my mind: Individual differences in the experience of stereotype threat. Journal of Experimental Social Psychology, 39 , 626-633.

Calvo, M.G., \& Eysenck, M.W. (2000). Early vigilance and late avoidance of threat processing: Repressive coping versus low/high anxiety. Cognition and Emotion, 14 (6), 763-787.

Cameron, J. (2001). Social Identity, Modern Sexism, and Perceptions of Personal and Group Discrimination. Sex Roles, 45(11), 743- 766.

Cameron, J. (2004). A three factor model of social identity. Self and Identity, 3(3), 239262.

Cantor, J. R. (1976). What is funny to whom? The role of gender. Journal of Communication, 26, 164-172.

Cogan, R., Cogan, D., Waltz,W., \&McCue, M. (1987). Effects of laughter and relaxation on discomfort thresholds. Journal of Behavioral Medicine, 10(2), 139-144.

Cooper, J., \& Fazio, R. H. (1984). A new look at dissonance theory. In L. Berkowitz (Ed.), Advances in experimental social psychology (Vol. 17, pp. 229-266). San Diego, CA: Academic.

Crandall, C. S., Eshleman, A., \& O'Brien, L. (2002). Social norms and the expression and suppression of prejudice: The struggle for internalization. Journal of personality and social psychology, 82(3), 359-378.

Cutler, M. (2006). Minority Group, Majority Space: Negotiating Jewish Identity in a Southern Christian Context. Journal of Contemporary Ethnography, 35, 696-728. 
Dan, A.J., Pinsof, D.A., \& Riggs, L.L. (1995). Sexual Harassment as an Occupational Hazard in Nursing. Basic and Applied Social Psychology, 17(4), 563-580.

Doosje, B., Ellemers, N., \& Spears, R. (1995). Perceived intragroup variability as a function of group status and identification. Journal of Experimental Social Psychology, 31, 410-436.

Ellemers, N., Spears, R., \& Doosje, B. (Eds.). (1999). Social identity: Context, commitment, content. Oxford, England: Blackwell Science.

Ellemers, N., R. Spears \& Doosje, B. (2002). Self and social identity. Annual Review of Psychology, 53, 161- 186.

Fine, G.A., De Soucey, M. (2005). Joking cultures: Humor themes as social regulation in group life. Humor, 18(1), 1-22.

Ford, T.E., Boxer, C.F., Armstrong, J., \& Edel, J.R. (2008). More that "Just a Joke": The Prejudice-Releasing Function of Sexist Humor. Personality and Social Psychology Bulletin, 34(2), 159-170.

Ford, T. E., \& Ferguson, M. A. (2004). Social consequences of disparagement humor: A prejudiced norm theory. Personality and Social Psychology Review, 8(1), 79-94.

Ford, T. E. (2000). Effects of sexist humor on tolerance of sexist events. Personality and Social Psychology Bulletin, 26, 1094-1107.

Foster, M. D., \& Matheson, K. (1998). Perceiving and feeling personal discrimination: Motivation or inhibition for collective action? Group Processes and Intergroup Relations, 1, 165-174.

Foster, M. D., \& Matheson, K. (1999). Perceiving and responding to the personal/group discrimination discrepancy. Personality and Social Psychology Bulletin, 25, 
1319-1329.

Fox, S. (1990). The ethnography of humor and the problem of social reality. Sociology $24(3), 431-446$.

Frijda, N. H. (1986). The emotions. Cambridge, UK: Cambridge University Press.

Gill, R., \& Matheson, K. (2006). Responses to discrimination: the role of emotion and expectations for emotional regulation. Personality and Social Psychology Bulletin, $32,149-161$.

Gordijn, E. H., Wigboldus, D., \& Yzerbyt, V. (2001). Emotional consequences of categorizing victims of negative outgroup behavior as ingroup or outgroup. Group Processes and Intergroup Relations, 4, 317-326.

Greenwood, D., \& Isbell, L. M. (2002). Ambivalent sexism and the dumb blonde: Men's and women's reactions to sexist jokes. Psychology of Women Quarterly, 26, 341350.

Hercus, C. (1999). Identity, Emotion, and Feminist Collective Action. Gender Society, $13,34-55$.

Hiller, H. H. (1983). Humor and hostility: A neglected aspect of social movement analysis. Qualitative Sociology, 6(3), 255-265.

Hornsey, M.J. (2005). Why being right is not enough: Predicting defensiveness in the face of group criticism. European Review of Social Psychology, 16(9), 301-334.

Hornsey, M. J., De Bruijn, P., Creed, J., Allen, J., Ariyanto, A., \& Svensson, A. (2005). Keeping it in-house: How audience affects responses to group criticism. European Journal of Social Psychology, 35(3), 291-312. 
Hornsey, M. J., Oppes, T., \& Svensson, A. (2002). "It's ok if we say it, but you can't": Responses to intergroup and intragroup criticism. European Journal of Social Psychology, 32(3), 293-307.

Hornsey, M. J., Spears, R., Cremers, I., \& Hogg, M. A. (2003). Relations between high and low power groups: The importance of legitimacy. Personality and Social Psychology Bulletin, 29(2), 216-227.

Hornsey, M. J., Trembath, M., \& Gunthorpe, S. (2004). 'You can criticize because you care': Identity attachment, constructiveness, and the intergroup sensitivity effect. European Journal of Social Psychology, 34, 499-518.

Insko, C. A., \& Schopler, J. (1998). Differential distrust of groups and individuals. In C. Sedikides, J. Schopler, \& C. A. Insko (Eds.), Intergroup cognition and intergroup behavior (pp. 75--107). Mahwah, NJ: Erlbaum.

Jetten, J., Spears, R., \& Manstead, A. S. R. (1997). Strength of identification and intergroup differentiation: The influence of group norms. European Journal of Social Psychology, 27, 603-609.

Jetten, J., Postmes, T., \& McAuliffe, B. J. (2002). "We're all individuals": Group norms of individualism and collectivism, levels of identification, and identity threat. European Journal of Social Psychology, 32, 189-207.

Jetten, J., \& Spears, R. (2003). The divisive potential of differences and similarities: The role of intergroup distinctiveness in intergroup differentiation. European Review of Social Psychology, 14, 203-241. 
Johns, M., Schmader, T., \& Lickel, B. (2005). Ashamed to be an American? The role of identification in predicting vicarious shame for anti-Arab prejudice after 9-11. Self and Identity, 4 (4), 331-348.

Kaiser, C. R. \& Miller, C. T. (2004). A stress and coping perspective on confronting sexism. Psychology of Women Quarterly, 28, 168-178.

Kazarian, S. S., \& Martin, R. A. (2004). Humor styles, personality, and well-being among Lebanese university students. European Journal of Personality, 18, 209-219.

Kirsh, G.A., \& Kuiper, N.A. (2003). Positive and negative aspects of sense of humor: Associations with the constructs of individualism and relatedness. Humor, 16 (1), $33-62$.

Knutson, B. (1996). Facial expression of emotion influence interpersonal trait inferences. Journal of Nonverbal Behavior, 20(3), 165 - 182.

Kuiper, N. A., Martin, R. A., \& Olinger, L. J. (1993). Coping humour, stress, and cognitive appraisals. Canadian Journal of Behavioural Science, 25, 81-96.

La Fave, L., \& Mannell, R. (1976). Does ethnic humor serve prejudice? Journal of Communication, 26, 116-123.

La Fave, L., Haddad, J., \& Maesen, W. A. (1996). Superiority, enhanced self-esteem, and perceived incongruity humor theory. In A. J. Chapman \& H. C. Foot (Eds.), Humor and laughter: Theory, research and applications (pp. 63-91). New York: Wiley.

LaFrance, M., \& Woodzicka, J. A. (1998). No laughing matter: Women's verbal and nonverbal reactions to sexist humor. In J. Swim \& C. Stangor (Eds.), Prejudice: The target's perspective (pp. 61-80). San Diego: Academic.

LaFrance, M., \& Woodzicka, J. (2001). Real versus imagined reactions to sexual 
harassment. Journal of Social Issues, 57(1), 15-30.

Lampert, M.D., \& Ervin-Tripp, S. (1998). Exploring paradigms: The study of gender and sense of humor near the end of the $20^{\text {th }}$ century. In W. Ruch (Ed.), The Sense of Humor: Explorations of a Personality Characteristic (pp. 231-270). Berlin: Walter de Gruyter.

Lawson, T.J., Downing, B. \& Cetola, H. (1998). An Attributional Explanation for the Effect of Audience Laughter on Perceived Funniness. Basic and Applied Social Psychology, 20 (4), 243-249.

Lefcourt H.M., \& Martin RA. (1986). Humour and life stress: antidote to adversity. New York: Springer-Verlag.

Lewis, M.D., \& Douglas, L. (1998). Emotion Regulation and Self-Organizing Defenses. In Mascolo, MF, \& Griffin, S. (Eds.) What Develops in Emotional Development?, (pp. 159-185). New York: Plenum Publishing.

Levine, J. B. (1976). The feminine routine. Journal of Communication, 26, 173-175.

Lickel, B., Schmader, T., \& Barquissau, M. (2004). The Evocation of Moral Emotions in Intergroup Contexts. In N.R. Branscombe, \& B. Doosje (Eds), Collective Guilt: International Perspectives (pp. 35-55). Australia and New Zealand: Cambridge University Press.

Losco, J., \& Epstein, S. (1975). Humor preference as a subtle measure of attitudes towards the same and opposite sex. Journal of Personality, 43, 321-334.

Love, A. M., \& Deckers, L. H. (1989). Humor appreciation as a function of sexual aggression and sexual content. Sex Roles, 20, 649-654. 
Lynch, O. H. (2002). Humorous communication: Finding a place for humor in communication research. Communication Theory, 12(4), 423-445.

Maass, A., Cadinu, M., Guarnieri, G., \& Grasselli, A. (2003). Sexual harassment under social identity threat: The computer harassment paradigm. Journal of Personality and Social Psychology, 85, 853-870.

Mackie, D.M., Devos, T., \& Smith, E.R. (2000). Intergroup Emotions: Explaining Offensive Action Tendencies in an Intergroup Context. Journal of Personality and Social Psychology, 79(4), 602-616.

Mackie, D.M., \& Smith, E.R. (2004). From Prejudice to Intergroup Emotions: Differentiated Reactions to Social Groups. Philadelphia, PA: Psychology Press.

MacKinnon, D.P., Lockwood, C.M., \& Williams, J. (2004). Confidence Limits for the Indirect Effect: Distribution of the Produce and Resampling Methods. Multivariate Behavioral Research, 39(1), 99-128.

Maio, G.R., Olson, J.M., \& Bush, J.E. (1997). Telling Jokes that Disparage Social Groups: Effects on the Joke Teller's Stereotypes. Journal of Applied Social Psychology, 27 (2), $1986-2000$.

Major, B. (2006). New perspectives on stigma and psychological well-being. In S. Levin \& C. van Laar (Eds.), Stigma and group inequality: Social psychological perspectives (pp. 193-210). Mahwah, N.J.: Lawrence Erlbaum Associates.

Marques, J. M., \& P_aez, D. (1994). The black sheep effect: Social categorization, rejection of ingroup deviates, and perception of group variability. In W. Stroebe \& M. Hewstone (Eds.), European review of social psychology (Vol. 5, pp. 37-68). New York: Wiley. 
Martin, R.A., \& Lefcourt, H.M. (1983). Sense of humor as a moderator of the relation between stressors and moods. Journal of Personality and Social Psychology, 45 , $1313-1324$.

Martin, R. A., Kuiper, N. A., Olinger, L. J., \& Dance, K. A. (1993). Humor, coping with stress, selfconcept, and psychological well-being. Humor: International Journal of Humor Research, 6, 89-104.

Matheson, K., Cole, B. \& Majka, K. (2003). Dissidence from within: Examining the effects of intergroup context on group members' reactions to attitudinal opposition. Journal of Experimental Social Psychology, 39, 161-169.

Matheson, K., \& Anisman, H. (2008). Anger and Shame Elicited by Discrimination: Moderating Role of Coping on Action. European Journal of Social Psychology.

McCoy, S. K., \& Major, B. (2003). Group identification moderates emotional responses to perceived prejudice. Personality and Social Psychology Bulletin, 29, 1005-1017.

McGhee, P.E. (1999). Health, healing and the amuse system: Humor as survival training ( $3^{\text {rd }}$ ed.). Dubuque, Iowa: Kendall/Hunt.

Meyer, J. C. (2000). Humor as a double-edged sword: Four functions of humor in communication. Communication Theory, 10,310-331.

Mitchell, C. (1977). The sexual perspective in the appreciation and interpretation of jokes, Western Folklore, 36, 303-329.

Mogg, K., McNamara, J., Powys, M., Rawlinson, H., Seiffer, A., \& Bailey, B.P. (2000). Selective attention to threat: A test of two cognitive models of anxiety. Cognition and Emotion, 14 (3), 375-399.

Moore, T. E., Griffiths, K., \& Payne, B. (1987). Gender, attitudes towards women, and 
the appreciation of sexist humor. Sex Roles, 16, 521-531.

Neitz, M. (1980). Humor, hierarchy, and the changing status of women. Psychiatry, 43, 211-223.

Nemeth, C., \& Owens, P. (1996). Making work groups more effective: The value of minority dissent. In The Handbook of Workgroup Psychology, West MA (ed.) (pp.125-141). Wiley: Chichester.

Overholser, J. C. (1992). Sense of humor when coping with life stress. Personality and Individual Differences, 13, 799-804.

Paulhus, D.L., Robins, R.W., Trzesniewski, K.H. \& Tracy, J.L. (2004). Two replicable suppressor situations in personality research. Multivariate Behavioral Research, $39,303-328$.

Paludi, M. A., \& Barickman, R. B. (1991). Academic and workplace sexual harassment. Albany: State University of New York Press.

Pennekamp, S. F., Doosje, B., Zebel, S., \& Fischer, A. H. (2007). The past and the pending: The antecedents and consequences of group-based anger in historically and currently disadvantaged groups. Group Processes \& Intergroup Relations, 10, $41-55$.

Platow, M.J., Haslam, S.A., Both, A., Chew, I., Cuddon, M., Goharpey, N., Maurer, J., Rosini, S., Tsekouras, A., \& Grace, D.M. (2005). "It's not funny if they're laughing: Self-categorization, social influence, and responses to canned laughter. Journal of Experimental Social Psychology, 41(5), 542-550. 
Preacher, K. J., \& Hayes, A. F. (2004). SPSS and SAS procedures for estimating indirect effects in simple mediation models. Behavior Research Methods, Instruments, \& Computers, 36, 717-731.

Preacher, K. J., \& Hayes, A.F. (2008). Asymptotic and resampling strategies for assessing and comparing indirect effects in multiple mediator models. Behaviour Research Methods, 40 (30), 879-891.

Rappoport, L. (2005). Punchlines: The Case for Racial, Ethnic, and Gender Humor, Westport, CT: Praeger.

Roseman, I. J. (1984). Cognitive determinants of emotion: A structural theory. In P. Shaver (Ed.), Review of personality and social psychology: Emotions, relationships, and health (pp. 11-36). Beverly Hills, CA: Sage.

Roseman, I.J. (1996). Appraisal Determinants of Emotions: Constructing a more accurate and comprehensive theory. Cognition and Emotion, 10(3), 241-277.

Ryan, K. M., \& Kanjorski, J. (1998). The enjoyment of sexist humor, rape attitudes, and relationship aggression in college students. Sex Roles, 38, 743-756.

Schmitt,M.T., \& Branscombe, N.R. (2001). The Meaning and Consequences of Perceived Discrimination in Disadvantaged and Priveleged Social Groups. European Review of Social Psychology, 12 (1), 167-199.

Seligman, M. E. P. (2002). Authentic Happiness: Using the New Positive Psychology to Realize Your Potential for Lasting Fulfillment. The Free Press: New York.

Seligman, M.E.P., Steen, T.A., Park, N., \& Peterson, C. (2005). Positive Psychology in Progress. American Psychologist, 60(5), 410-421. 
Smith, C. A. \& Ellsworth, P. C. (1985). Patterns of cognitive appraisal in emotion. Journal of Personality \& Social Psychology, 48, 813-838.

Spears, R., Doosje, B., \& Ellemers, N. (1999). Commitment and context in the social perception. In N. Ellemers, R. Spears, \& B. Doosje (Eds.), Social identity: context, commitment, content. (pp. 59-83). Oxford, UK: Blackwell.

Swim, J. K., \& Hyers, L. L. (1999). Excuse me — what did you just say?! Women's public and private reactions to sexist remarks. Journal of Experimental Social Psychology, 35(1), 68-88.

Swim, J.K., Aikin, K.J., Hall, W.S., \& Hunter, B.A. (1995). Sexism and racism: oldfashioned and modern prejudices. Journal of personality and social psychology, 68(2), 199-214.

Swim, J.K., Hyers, L.L., Cohen, L.L., \& Ferguson, M.J. (2001). Everyday Sexism: Evidence for its incidence, nature, and psychological impact from three daily diary studies. Journal of Social Issues, 57(1), 31-53.

Stangor, C., \& Crandall, C.S. (2003). Threat and the Social Construction of Stigma. In Heatherton, T.F., Kleck, R.E., Hebl, M.R., \& Hull, J.G. (Eds.) The Social Psychology of Stigma, (pp. 62-87) New York: Guilford Press.

Tabachnick, B.G., \& L.S. Fidell (2001). Using Multivariate Statistics. Fourth Edition. Boston: Allyn and Bacon.

Tangney, J.P. (1995). Shame and guilt in interpersonal relationships. In J.P. Tangney \& K.W. Fischer (Eds.) Self-conscious emotions (pp. 64-113). New York: Guilford Press.

Tangney, J.P., Dearing, R. (2002). Shame and guilt. New York: Guilford. 
Tajfel, H. (1978). Differentiation Between Social Groups: Studies in the social psychology of intergroup relations. Academic Press: London.

Tajfel, H., \& Turner, J. C. (1979). An integrative theory of intergroup conflict. In W. G. Austin \& S. Worchel (Eds.), The social psychology of intergroup relations (pp. 3347). Monterey, CA: Brooks/Cole.

Terrion, J. L., \& Ashforth, B. E. (2002). From "I' to "we': The role of putdown humor and identity in the development of a temporary group. Human Relations, 55(1), 55-88.

Thomas, C. A., \& Esses, V. M. (2004). Individual differences in reactions to sexist humor. Group Processes \& Intergroup Relations, 7(1), 89-100.

Tracy, J.L., \& Robins, R.W. (2004). Show Your Pride : Evidence for a Discrete Emotion Expression. Psychological Science, 15 (3), $194-197$.

Tropp, L. R., \& Bianchi, R. A. (2007). Interpreting references to group membership in context: Feelings about intergroup contact depending on who says what to whom. European Journal of Social Psychology, 37(1), 153-170.

Vaillant, G. E. (2000). Adaptive Mental Mechanisms: Their Role in a Positive Psychology. American Psychologist, 55(1), 89-98.

van Zomeren, M., Spears, R., Fischer, A., \& Leach, C. W. (2004). Put your money where your mouth is! Explaining collective action tendencies through group-based anger and group efficacy. Journal of Personality and Social Psychology, 87, 649-664.

Vivian, J. E., \& Berkowitz, N. H. (1992). Anticipated bias from an outgroup: An attributional analysis. European Journal of Social Psychology, 22, 415-424.

Wagg, S.(1998). Punching your weight. In S. Wagg (Ed.). Because I tell a joke or two: Comedy, Politics, and Social Difference (pp. 111-136). New York: Routledge. 
Walker, Nancy (1981). Do feminists ever laugh?: Womens' humor and womens' rights. International Journal of Women's Studies 4, 1-9.

Wicker, F. W., Barron, W. L., III, \& Willis, A. C. (1980). Disparagement humor: Dispositions and resolutions. Journal of Personality and Social Psychology, 39, 701-709.

Wicker, F.W., Payne, G.C., \& Morgan, R.D. (1983). Participant descriptions of guilt and shame. Motivation and Emotion, 7, 25-39.

Wills, T. A. (1981). Downward comparison principles in social psychology. Psychological bulletin, 90(2), 245-271.

Wright, S. C., Taylor, D. M., \& Moghaddam, F. M. (1990). Responding to membership in a disadvantaged group from acceptance to collective protest. Journal of Personality and Social Psychology, 58, 994-1003.

Wright, S.C., \& Taylor, D.M. (2003) The Social Psychology of Cultural Diversity: Social Stereotyping, Prejudice, and Discrimination. In M.A. Hogg \& J. Cooper (Eds.) The Sage Handbook of Social Psychology (pp. 432 - 457). London: Sage Publications.

Yedes, J. (1996). Playful teasing: Kiddin' on the square. Discourse And Society 7 (3), $417-438$.

Yzerbyt, V., Dumont, M., Wigboldus, D., \& Gordijn, E. (2003). I feel for us: the impact of categorization and identification on emotions and action tendencies. British Journal of Social Psychology, 42, 533-549.

Zajdman, A. (1995). Humorous face-threatening acts: Humor as strategy. Journal of Pragmatics, 23(3), 325-339.

Zillmann, D., \& Cantor, J. R. (1976). A disposition theory of humor and mirth. In A. 
J.Chapman \& H. C. Foot (Eds.), Humor and laughter: Theory, research and applications (pp. 93-116). New York: Wiley.

Ziv, A. (1984). Personality and Sense of Humor. New York: Springer.

Ziv, A.(1998). Jewish Humor. United States of America: Transaction Publishers. 
APPENDIX A

Pre-Joke Measures 


\section{Mood}

Your current mood can sometimes influence how you react to what happens around you. Using the rating scale beside each item, please indicate how much each adjective describes how you feel at the moment. There are no right or wrong answers, we just want you to be as honest as possible in indicating how you're feeling right now.

\begin{tabular}{|c|c|c|c|c|c|c|c|c|}
\hline$\ldots \ldots \ldots$ Not at all & 0 & 1 & 2 & 3 & 4 & 5 & 6 & Extremely \\
\hline Not at all & 0 & 1 & 2 & 3 & 4 & 5 & 6 & Extremely \\
\hline Annoyed... & 0 & 1 & 2 & 3 & 4 & 5 & 6 & Extremely \\
\hline .......... Not at all & 0 & 1 & 2 & 3 & 4 & 5 & 6 & Extremely \\
\hline Attentive............... Not at all & 0 & 1 & 2 & 3 & 4 & 5 & 6 & Extremely \\
\hline Not at all & 0 & 1 & 2 & 3 & 4 & 5 & 6 & Extremely \\
\hline Disgusted.............. Not at all & 0 & 1 & 2 & 3 & 4 & 5 & 6 & Extremely \\
\hline Distressed............. Not at all & 0 & 1 & 2 & 3 & 4 & 5 & 6 & Extremely \\
\hline Embarrassed........... Not at all & 0 & 1 & 2 & 3 & 4 & 5 & 6 & Extremely \\
\hline Enraged................ Not at all & 0 & 1 & 2 & 3 & 4 & 5 & 6 & Extremely \\
\hline Enthusiastic..............Not at all & 0 & 1 & 2 & 3 & 4 & 5 & 6 & Extremely \\
\hline Excited.......... & 0 & 1 & 2 & 3 & 4 & 5 & 6 & Extremely \\
\hline Frustrated............... Not at all & 0 & 1 & 2 & 3 & 4 & 5 & 6 & Extremely \\
\hline Happy.................. Not at all & 0 & 1 & 2 & 3 & 4 & 5 & 6 & Extremely \\
\hline Hostile................. Not at all & 0 & 1 & 2 & 3 & 4 & 5 & 6 & Extremely \\
\hline Humiliated............. Not at all & 0 & 1 & 2 & 3 & 4 & 5 & 6 & Extremely \\
\hline Indifferent..... & 0 & 1 & 2 & 3 & 4 & 5 & 6 & Extremely \\
\hline Infuriated....... & 0 & 1 & 2 & 3 & 4 & 5 & 6 & Extremely \\
\hline Inspired......... & 0 & 1 & 2 & 3 & 4 & 5 & 6 & Extremely \\
\hline Interested............. Not at all & 0 & 1 & 2 & 3 & 4 & 5 & 6 & Extremely \\
\hline Irritable....... & 0 & 1 & 2 & 3 & 4 & 5 & 6 & Extremely \\
\hline Out of place. & 0 & 1 & 2 & 3 & 4 & 5 & 6 & Extremely \\
\hline .. Not at all & 0 & 1 & 2 & 3 & 4 & 5 & 6 & Extremely \\
\hline Not at all & 0 & 1 & 2 & 3 & 4 & 5 & 6 & Extremely \\
\hline Strong .................. Not at all & 0 & 1 & 2 & 3 & 4 & 5 & 6 & Extremely \\
\hline Unhappy......... & 0 & 1 & 2 & 3 & 4 & 5 & 6 & Extremely \\
\hline Uncomfortable.......... Not at all & 0 & 1 & 2 & 3 & 4 & 5 & 6 & Extremely \\
\hline
\end{tabular}


APPENDIX B

Disparaging and Non-Disparaging Joke Stimuli 


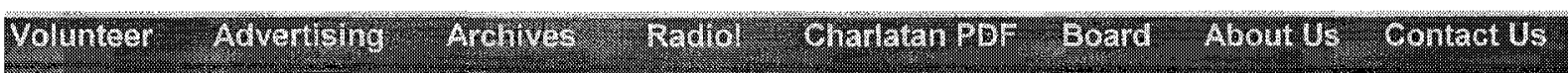

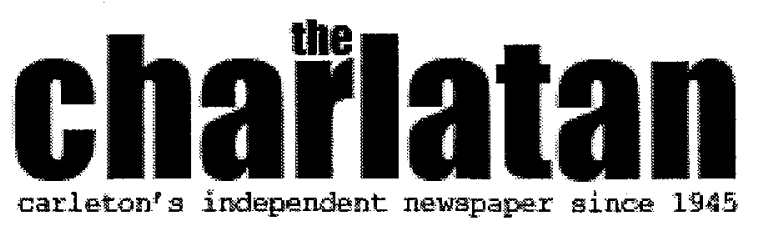

Front Page | News | National | Perspectives | Features | Opinion | Arts | Sports | Search Photo Galleries |

\section{Dp-and-coming Comics to Visit Carleton Campus?}

\section{by.J. Butter.}

Want to take a break from your studies? Searching for that special release from the everyday humdrum? Looking for something to do on a boring weeknight? If so, look no further, since the Carleton University Students Association (CUSA) is brewing up a campus event like no other. How about registering for a night of Humor 101? CUSA wants to make comedy a monthly event on campus, and sponsoring Humor 101 - an event showcasing upand-coming comics right here on campus - is exactly how they plan to do it. But before CUSA starts hosting Humor 101, they would like the students to assist them in choosing who fits the bill. To have your say and choose who should perform their comedy on campus, please visit our polling station at: http://www.pickyourcampuscomic@carleton.ca.

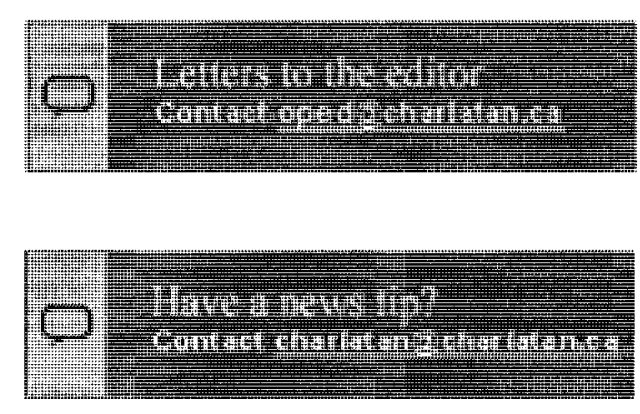

Charlatan Publications Inc.

Web Development \& Design by BIONIQ [+]FEEDEACK REs:

(Note: this is the Repressive Male Condition) 


\section{Pick your Campus Comic Polling Station}

\section{Kevin Bentley}

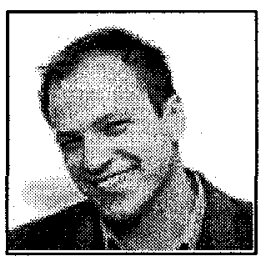

- Performed in college circuits in the United States and the U.K.

- Other acts include stand-up at Yuk Yuk's and JR's Last Laugh

Jokes by Kevin Bentley

I don't like thank you cards, because I don't know what else to say. What should I put on the inside? Thanks... (open the card) "A lot" or "See front". I just find these kinds of cards find really redundant. You should write something in them that they don't know... Like, "Thank you... (open the card) "By the way, I fear dolphins".

Please rate how funny the joke above was:
Not at all $=0$
$1 .$.
.2.
3.
4.
5.
$6=$ Extremely

Did you ever notice how bananas and streetlight colours mean opposite things? With streetlights, green means go, yellow means slow down and red means stop. With bananas, green means stop, yellow means go, and red means, where the hell did you get that banana?!

Please rate how funny the joke above was:

Not at all $=0$ 1. 2 ..3. 4. .5 . 6 $=$ Extremely

A male-to-female transsexual was recently interviewed on a radio talk show. The DJ asked the transsexual about what, if any, pain the person experienced during the operation. The transsexual replied, "Well, when they cut my penis off, that really didn't hurt too much. Even when they implanted the breasts in my chest, well, it didn't hurt too much either...."

"Then you didn't experience any real physical pain at all then?"

"Well, it hurt like hell when they stuck that big f*cking needle in my head and sucked out all my brains.

Please rate how funny the joke above was:

Not at all $=0$ 1. .2 .3 4... .5. 6= Extremely 


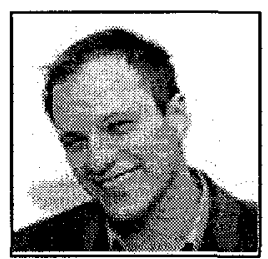

More Jokes by Kevin Bentley

Here are 5 things you wouldn't know without movies:

1 - It is always possible to park directly outside any building you are visiting.

2 - A detective can only solve a case once he has been suspended from duty.

3 - If you decide to start dancing in the street, everyone you bump into will know all the steps.

4 - It doesn't matter if you are heavily outnumbered in a fight involving martial arts - your enemies will wait patiently to attack you one by one by dancing around in a threatening manner until you have knocked out their predecessors.

5 - Television news bulletins usually contain a story that affects you personally at that precise moment you turn the television on.

Please rate how funny the joke above was:

Not at all $=0$ .1 .

2

3.

4

5. 6= Extremely

Here's something good to know:

Recently scientists revealed that beer contains small traces of female hormones. To prove their theory, the scientists fed 100 men 12 pints of beer and observed that $100 \%$ of them gained weight, talked excessively without making sense, became emotional, couldn't drive, and refused to apologize when wrong. No further testing is planned.

Please rate how funny the joke above was:

Not at all $=0$

.1 .

2 .

.3

.4.

5 .

6= Extremely

This one's for you, ladies:

Three women were granted one wish each by a genie. The first woman said, "I wish I was the smartest woman in the world." And POOF, it came to be. The second woman said, "I wish I was ten times smarter than the smartest woman in the world." And POOF, this too came to be. The third woman said, "I wish I was twenty times smarter than the smartest woman in the world." . . And POOF, she was a man.

Please rate how funny the joke above was:

Not at all $=0$ 1 2. 3 . $.4 \ldots \ldots \ldots \ldots$ 6= Extremely

\section{End of Survey}

(Note: this is the Self-deprecating Female condition) 


\section{Pick your Campus Comic Polling Station}

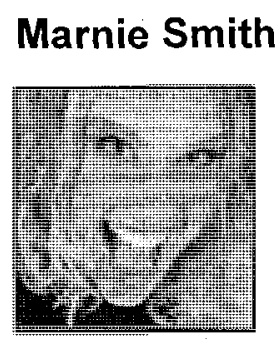

- Performed in college circuits in the United States and the U.K.

- Other acts include stand-up at Yuk Yuk's and JR's Last Laugh

Jokes by Marnie Smith

I don't like thank you cards, because I don't know what else to say. What should I put on the inside? Thanks... (open the card) "A lot" or "See front". I just find these kinds of cards find really redundant. You should write something in them that they don't know... Like, "Thank you... (open the card) "By the way, I fear dolphins".

Please rate how funny the joke above was:

Not at all $=0$ 1 ... 2 . .3. .4 .5 $6=$ Extremely

Did you ever notice how bananas and streetlight colours mean opposite things? With streetlights, green means go, yellow means slow down and red means stop. With bananas, green means stop, yellow means go, and red means, where the hell did you get that banana?!

Please rate how funny the joke above was:

Not at all $=0$ 1. 2. ...3. 4 . .5 $6=$ Extremely

A male-to-female transsexual was recently interviewed on a radio talk show. The DJ asked the transsexual about what, if any, pain the person experienced during the operation. The transsexual replied, "Well, when they cut my penis off, that really didn't hurt too much. Even when they implanted the breasts in my chest, well, it didn't hurt too much either...."

"Then you didn't experience any real physical pain at all then?"

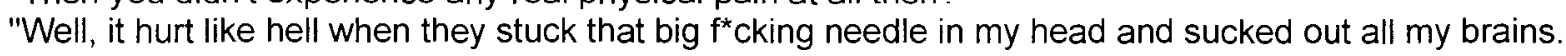

Please rate how funny the joke above was:

Not at all $=0$ 1. .2 ..3. .4. .5. 6= Extremely 


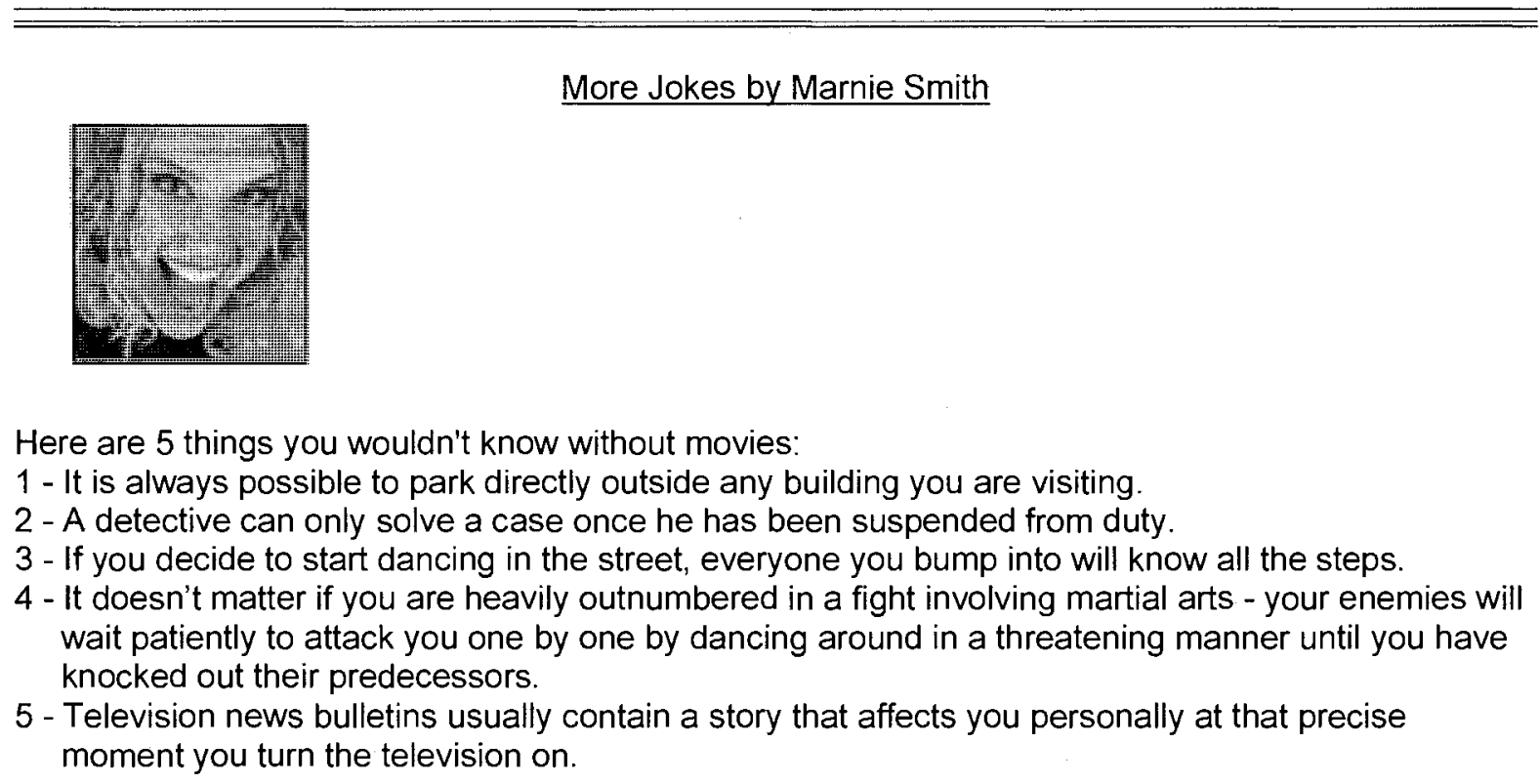

Please rate how funny the joke above was:

Not at all $=0$ $1 \ldots . . . . . . .2$. .3. 4. .5. $6=$ Extremely

Here's something good to know:

Recently scientists revealed that beer contains small traces of female hormones. To prove their theory, the scientists fed 100 men 12 pints of beer and observed that $100 \%$ of them gained weight, talked excessively without making sense, became emotional, couldn't drive, and refused to apologize when wrong. No further testing is planned.

Please rate how funny the joke above was:

Not at all $=0$ .1. $2 \ldots \ldots \ldots . . . . .3$. 4. .5. $6=$ Extremely

This one's for you, ladies:

Three women were granted one wish each by a genie. The first woman said, "I wish I was the smartest woman in the world." And POOF, it came to be. The second woman said, "I wish I was ten times smarter than the smartest woman in the world." And POOF, this too came to be. The third woman said, "I wish I was twenty times smarter than the smartest woman in the world." .. . And POOF, she was a man.

Please rate how funny the joke above was:

Not at all $=0$ 1. .2. ...3. .4 .5 6= Extremely

\section{End of Survey}


(Note: this is the Observational Male Condition)

| Back to the Charlatan |

\section{Pick your Campus Comic Polling Station}

\section{Kevin Bentley}

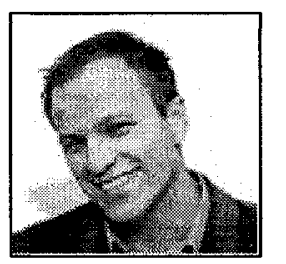

- Performed in college circuits in the United States and the U.K.

- Other acts include stand-up at Yuk Yuk's and JR's Last Laugh

Jokes by Kevin Bentley

I don't like thank you cards, because I don't know what else to say. What should I put on the inside? Thanks... (open the card) "A lot" or "See front". I just find these kinds of cards find really redundant. You should write something in them that they don't know... Like, "Thank you... (open the card) "By the way, I fear dolphins".

Please rate how funny the joke above was:
Not at all $=0$
.1.
2.
3.
4.
.5
6= Extremely

Did you ever notice how bananas and streetlight colours mean opposite things? With streetlights, green means go, yellow means slow down and red means stop. With bananas, green means stop, yellow means go, and red means, where the hell did you get that banana?!

Please rate how funny the joke above was:
Not at all $=0$
.1.
.2
3.
4.
5
6= Extremely

I am so tired of having to come up with another outfit for myself everyday. In fact, I will say this-and I think many people agree with me-I think eventually fashion won't even exist. I think someday we'll all wear the same thing. Because anytime I see a movie or a TV show where there are people from the future or another planet, they're all wearing the same outfit. Somehow they all decided, "All right, that's enough. From now on, this is going to be our outfit: A one-piece silver jumpsuit, with a V-stripe on the chest, and boots. That's it! We're going to start visiting other planets and we want to look like a team."

Please rate how funny the joke above was:

Not at all $=0$ 1. .2 . .3 . .4 .5. 6= Extremely 


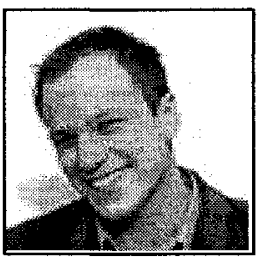

\section{More Jokes by Kevin Bentley}

Here are 5 things you wouldn't know without movies:

1 - It is always possible to park directly outside any building you are visiting.

2 - A detective can only solve a case once he has been suspended from duty.

3 - If you decide to start dancing in the street, everyone you bump into will know all the steps.

4 - It doesn't matter if you are heavily outnumbered in a fight involving martial arts - your enemies will wait patiently to attack you one by one by dancing around in a threatening manner until you have knocked out their predecessors.

5 - Television news bulletins usually contain a story that affects you personally at that precise moment you turn the television on.

Please rate how funny the joke above was:

Not at all $=0$ $1 \ldots \ldots \ldots . . . .2$ ..3. 4. 5 6= Extremely

I think the worst time to choke on something would be during a game of charades. Especially if your teammates are bad guessers. The only time worse than that would be during a game of fake choking attack, followed by a nap.

Please rate how funny the joke above was:

Not at all $=0$ 1. 2 ..3. .4. .5 . 6= Extremely

I think batteries are the most dramatic objects of all the objects. Because other things just stop working or they break. But batteries, they die. If you're a battery, you're either working or you're dead - that's a horrible life.

Please rate how funny the joke above was:
Not at all $=0$ 1. 2.............3 .4. $.5 \ldots \ldots \ldots .6=$ Extremely

\section{End of Survey}


(Note: this is the Observational Female condition)

| Back to the Charlatan|

\section{Pick your Campus Comic Polling Station}

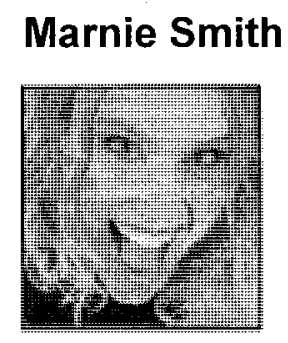

- Performed in college circuits in the United States and the U.K.

- Other acts include stand-up at Yuk Yuk's and JR's Last Laugh

Jokes by Marnie Smith

I don't like thank you cards, because I don't know what else to say. What should I put on the inside? Thanks... (open the card) "A lot" or "See front". I just find these kinds of cards find really redundant. You should write something in them that they don't know... Like, "Thank you... (open the card) "By the way, I fear dolphins".

Please rate how funny the joke above was:
Not at all $=0$
1.
.2.
3.
4 .
5
6= Extremely

Did you ever notice how bananas and streetlight colours mean opposite things? With streetlights, green means go, yellow means slow down and red means stop. With bananas, green means stop, yellow means go, and red means, where the hell did you get that banana?!

Please rate how funny the joke above was:

Not at all $=0$

1.

2

...3.

4.

.5.

6= Extremely

I am so tired of having to come up with another outfit for myself everyday. In fact, I will say this-and I think many people agree with me-l think eventually fashion won't even exist. I think someday we'll all wear the same thing. Because anytime I see a movie or a TV show where there are people from the future or another planet, they're all wearing the same outfit. Somehow they all decided, "All right, that's enough. From now on, this is going to be our outfit: A one-piece silver jumpsuit, with a V-stripe on the chest, and boots. That's it! We're going to start visiting other planets and we want to look like a team."

Please rate how funny the joke above was:

Not at all $=0$

1.

2

.3

.4.

.5 6= Extremely 


\section{More Jokes by Marnie Smith}

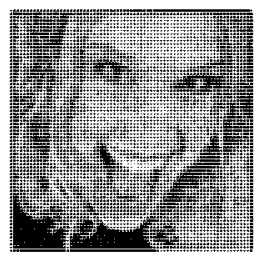

Here are 5 things you wouldn't know without movies:

1 - It is always possible to park directly outside any building you are visiting.

2 - A detective can only solve a case once he has been suspended from duty.

3 - If you decide to start dancing in the street, everyone you bump into will know all the steps.

4 - It doesn't matter if you are heavily outnumbered in a fight involving martial arts - your enemies will wait patiently to attack you one by one by dancing around in a threatening manner until you have knocked out their predecessors.

5 - Television news bulletins usually contain a story that affects you personally at that precise moment you turn the television on.

Please rate how funny the joke above was:

Not at all $=0$ 1. .2. 3. 4. 5 . 6= Extremely

I think the worst time to choke on something would be during a game of charades. Especially if your teammates are bad guessers. The only time worse than that would be during a game of fake choking attack, followed by a nap.

Please rate how funny the joke above was:

Not at all $=0$ 2 3. .4 . .5 . 6= Extremely

I think batteries are the most dramatic objects of all the objects. Because other things just stop working or they break. But batteries, they die. If you're a battery, you're either working or you're dead - that's a horrible life.

Please rate how funny the joke above was:

Not at all $=0$ $.1 .$. 2. .3. .4. .5 . $6=$ Extremely

\section{End of Survey}


APPENDIX C

Post-Joke Measures 


\section{Personal Evaluations of the Comic}

We are interested in your impressions of what the comic had to say. Please rate the following items using the scale of $0=$ "Not at all" to 6 = "Extremely":

Not at all $=0$ .1 2. 3 .4 .5 . $6=$ Extremely

1) I feel like laughing at what the comic said.

2) I am annoyed with what the comic said.

3) I feel happy after reading the comic's jokes.

4) I was bored with what the comic said.

5) I don't care either way about what the comic said.

6) I am pleased with the comic's jokes.

7) I am distressed about what the comic said.

8) I am angry with what the comic said.

9) I feel personally embarrassed after hearing the comic's jokes.

10) I feel ashamed that I found the comic's jokes funny.

11) I feel cheerful after reading the comic's jokes.

12) I feel out of place with what the comic said.

13) I feel embarrassed for the comic.

14) I feel uncomfortable with what the comic said.

Please provide your OVERALL impressions of the comic and their jokes

Not at all $=0$ .1 . .2 .3 .4 .5 . 6= Extremely

1) How funny were the jokes?

2) How creative were the jokes?

3) How likely are you to repeat these jokes to a friend? 
4) The comic you provided feedback on was

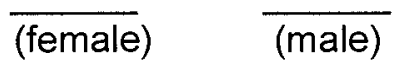

Not at all $=0$ .1 . .2 .3 .4 5. $6=$ Extremely

5) How offensive were these jokes?

6) How aggressive did the comic's jokes sound?

7) How friendly or likable do you think the comic is?

8) How well-written were the jokes?

9) How much of what the comic said is true of women?

$\ldots$ is true of people?

$\ldots$ is true of men?

10) How much of what the comic said is true of the events or observations mentioned?

11) a) Was the comic sexist?

11) b) Was the comic racist?

11) c) Was the comic homophobic?

12) Do you think the comic intended for their jokes to be liked by everyone?

13) Do you think the comic intended for their jokes to be offensive?

14) These jokes were exploitive of certain groups (e.g., women, etc.)

15) Do you think the comic intended for their jokes to cause harm, threaten or upset others?

16) Have you heard these jokes before?

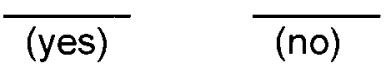

If yes, which ones? :
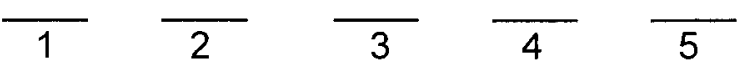


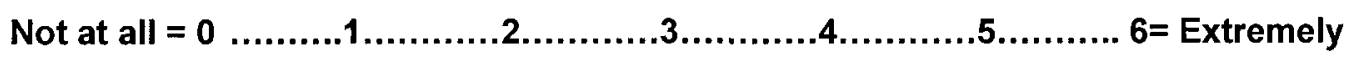

17) These jokes were hypocritical or two-faced.

18) These jokes give the impression that the comic doesn't like women. 


\section{Actions}

If you were given the opportunity to provide feedback on the comic's jokes and inform CUSA as to whether or not this comic should come to perform on campus, what concrete actions might you have taken? Please rate how likely it is that you would take each of the following actions.

Not at all $=0$ 1. 3 4..............5. 6= Extremely

1. I would really like to see this comic perform at Carleton.
0
1
2
3
4
5
6

2. I would pay admission to see this comic in the amount of:

$$
\begin{array}{lllll}
0 & \$ 5 & \$ 10 & \$ 15 & \$ 20
\end{array}
$$

3. I would make a point of going to see this comic perform.
0
1
2
3
4
$5 \quad 6$

4. I would tell my friends that they should go to see this comic.
0
1
2
3
4
5
6

5. I don't really care one way or another if the comic comes to campus.
0
1
2
3
4
5
6

6. The comic can come to campus, but I have no interest in going to hear him or her.
0
1
2
3
4
5
6

7. I would make a point of telling my friends not to go see this comic if s/he came to campus
0
1
2
3
4
5
6

8. I will personally write to CUSA letting them know that I do not believe this comic should be allowed to perform on campus.

0

1

2

3

4

5

6 
Not at all $=0$ .2 3 .4. .5 . $6=$ Extremely

9. I would personally go to the CUSA office and tell them that this comic should not be allowed to perform on campus.
0
1
2
3
4
5
6

10. If someone organized a petition stating that the students of Carleton University do not want this comic to perform on campus, I would sign it.
0
1
2
3
4
5
6

11. I hope this study shows CUSA that this comic should not be invited to come.
0
1
2
3
4
5
6

12. I would be willing to join others in a protest against this comic's performance at the University.
0
1
2
3
4
5
6

13. If CUSA still allowed the comic to perform, I would try to be one of the first people at the event and heckle or boo the comic.
0
1
2
3
4
$5 \quad 6$

14. If CUSA still allowed the comic to perform, I would attend the event with a group of friends and we would all heckle or boo the comic.
0
1
2
3
4
5
6

15. Go to the media (e.g. call in to a campus or local radio station; write an opinion letter to the local or campus paper (The Charlatan)) to express how inappropriate I think this comic is and that they should not come to campus.
0
1
2
3
4
5
6 


\section{Identification Scale}

Using the scale below, please rate the extent to which you agree or disagree with each of the statements below as it relates to you and your gender on a scale of 0 (strongly disagree) to 6 (strongly agree).

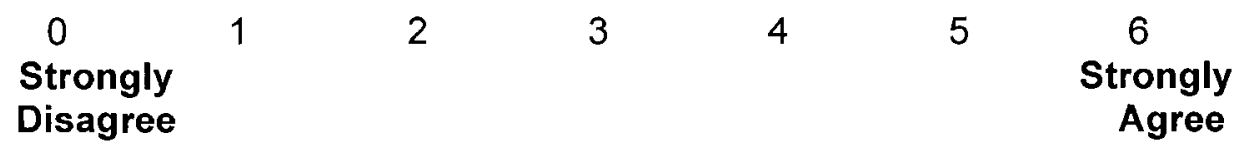

1) I have a lot in common with other women/men.

2) I often think about the fact that I am a woman/man.

3) In general, I'm glad to be a woman/man

4) The fact that I am a woman/man rarely enters my mind.

5) Generally, I feel good when I think about myself as a woman/man.

6) I feel strong ties to other women/men.

7) I often regret that I am a woman/man.

8) Overall, being a woman/man has very little to do with how I feel about myself.

9) I don't feel good about being a woman/man.

10) I find it difficult to form a bond with other women/men.

11) In general, being a woman/man is an important part of my self-image.

12) I don't feel a sense of being "connected" with other women/men. 


\section{Footnotes}

${ }^{1}$ Some clarification on the type of humor investigated in some earlier studies is necessary. Earlier humor research suggested that women were more likely to approve of and enjoy 'self-disparaging' jokes more than their male counterparts (Cantor, 1976; Losco \& Epstein, 1975; Zillmann \& Cantor, 1976). Specifically, jokes that deprecated females were found to be funnier by both genders; however, males did not find jokes that deprecated their own gender to be funny. However, in none of these studies did the jokes involve self-disparagement of a female by a female. Instead, self-disparaging humor in these studies only referred to jokes in which either females or males were ridiculed by the opposite sex (e.g. males ridiculing females or females ridiculing males). Taking the authors' misnomer of self-deprecating humor into account, their studies did not vary the gender of the joke-teller and thus only investigated repressive humor.

${ }^{2}$ Data was also collected from 55 male participants for exploratory purposes and not for analyses in the present study.

${ }^{3}$ Although it was not expected that participants would perceive the jokes as racist, 21 rated the jokes as such. Further examination into participant ethnicity and racism scores revealed no patterns of concern. All other scores for these participants were thus retained in the final sample.

${ }^{4}$ Although the statistical power of the hierarchical regressions performed were compromised using the mass-testing gender identification scores $(n=44)$, analyses were conducted on both the overall gender identification as well as its three dimensions (ingroup affect, ingroup ties, and centrality) to observe differences in effect size relative to the overall sample's merged ingroup affect scores $(n=137)$. In comparison to the $\mathrm{r}$ - 
squared change values obtained using the full sample of ingroup affect scores, similar or smaller effect sizes were obtained across all gender identity dimensions on most of the dependent variables. Additionally, all of these $p$ values were much less significant. Furthermore, a few of the dependent variables did show higher $r$-squared change values, but they did not often meet the $.05 p$ level of significance. These results should be interpreted with caution, since the mass-testing gender identification sample size does not meet the standard rule of thumb for testing beta coefficients $(N>104+$ number of independent variables, as stated in Tabachnick \& Fidell, 2001). 